DOI: 10.32089/WBH.PHW.2021.1(275).0005

orcid.org/0000-0002-1385-3016

\author{
PRZEMYSEAW BENKEN
}

Oddziałowe Biuro Badań Historycznych Instytutu Pamięci Narodowej w Szczecinie

\title{
Problematyka wykorzystania 1 Batalionu Szturmowego w operacji „Dunaj”
}

\begin{abstract}
The subject of this article is to present the activities of the 1st Assault Battalion during the operation „Danube” in 1968. Thanks to the archival queries in the Archive of the Institute of National Remembrance in Warsaw and in the Military Archive in Oleśnica, it was possible to prepare the most complete description of the activity of Polish special units in Czechoslovakia so far. The conducted research showed that the special forces were not used in accordance with their intended purpose, which had a negative impact on the effectiveness and morale of soldiers.

Udział Wojska Polskiego w interwencji w Czechosłowacji w 1968 r. dał pierwszą możliwość wykorzystania w warunkach bojowych jednostek specjalnych (m.in. elementów 1 Batalionu Szturmowego /1 bszt/ z Dziwnowa). $\mathrm{Z}$ tego też względu działania prowadzone przez tę młodą jednostkę (1 bszt sformowano w 1964 r. na bazie krakowskiego 26 Batalionu Rozpoznawczego $)^{1}$ wkrótce po zakończeniu działań w Czechosłowacji stały się obiektem

$1 \quad 1$ Batalion Szturmowy (1 bszt) nawiązywał do tradycji Polskiego Samodzielnego Batalionu Specjalnego (PSBS) sformowanego 18 X 1943 r. na rozkaz dowódcy I Korpusu Polskich Sił Zbrojnych na Wschodzie w Biełomutach (obwód moskiewski). Zadaniem jednostki było szkolenie grup i oddziałów, które przeznaczono do działań dywersyjno-rozpoznawczych na tyłach wroga. W sierpniu 1944 r. batalion przekazano do dyspozycji kierownika resortu bezpieczeństwa Polskiego Komitetu Wyzwolenia Narodowego. Od tego czasu oddział „wykonywał nowe zadania wynikające z potrzeb resortu”, co wiązało się z przerzuceniem go ze Związku Socjalistycznych Republik Sowieckich w okolice Lublina. Dokonania batalionu w oficjalnej dokumentacji opisano następująco: „udzielanie pomocy władzom Polskiego Komitetu Wyzwolenia Narodowego przy organizacji pracy partyjno-propagandowej, demaskowanie i unieszkodliwianie wrogich elementów”. PSBS został rozwiązany w listopadzie 1944 r.,
\end{abstract}


pogłębionych analiz. Mimo iż oficjalnie podkreślano profesjonalizm polskich żołnierzy, Sztab Generalny WP miał świadomość braków w przygotowaniu 1 bszt do prowadzenia działań specjalnych, które ujawniły się w toku operacji „Dunaj”.

Celem niniejszego artykułu jest zaprezentowanie kompleksowej analizy działań 1 bszt w operacji „Dunaj”. Autor sięgnął nie tylko do istniejącej literatury przedmiotu ${ }^{2}$, lecz przede wszystkim zapoznał się z materiałami archiwalnymi zgromadzonymi m.in. w Archiwum Instytutu Pamięci Narodowej w Warszawie i Archiwum Wojskowym w Oleśnicy. ${ }^{3}$ Pozwoliło to ująć problem relatywnie szczegółowo, jak również sformułować wniosek o niedostatecznej gotowości polskich sił specjalnych do prowadzenia działań

zob. Archiwum Instytutu Pamięci Narodowej w Warszawie (dalej: AIPN), Szefostwo Wojskowej Służby Wewnętrznej w Warszawie (dalej: SWSW), 2386/33555, 1 Batalion Szturmowy - historia, zadanie, przeznaczenie, Warszawa, 24 IX 1986 r., 7; Biblioteka byłych wojskowych organów bezpieczeństwa państwa polskiego (Wojskowej Służby Wewnętrznej oraz Zarządu II Sztabu Generalnego WP) (dalej: Biblioteka WSW oraz Zarządu II SG), 2603/2417, Tadeusz Limanowski, Wiesław Zajdziński, Użycie grup specjalnych w operacji zaczepnej frontu i armii. Zespołowa praca doktorska, cz. I, Warszawa 1988, 98-129. Do tradycji PSBS odwołał się także dowódca 1 bszt, ppłk Tadeusz Wandzel, w rozkazie specjalnym z okazji 25. rocznicy powstania tzw. ludowego Wojska Polskiego, którą 1 bszt świętował w Czechosłowacji: „W tym samym czasie, gdy 1. Dywizja Piechoty im. Tadeusza Kościuszki po zwycięskiej bitwie pod Lenino wyruszyła w dalszą drogę ku Polsce, rozpoczęła się organizacja i szkolenie Polskiego Samodzielnego Batalionu Specjalnego przeznaczonego dla przygotowywania kadr dla rozwijającej się w kraju ludowej partyzantki. Jako spadkobiercy chlubnych tradycji bojowych Ludowego Wojska Polskiego, dziś w odmiennych warunkach, bo we wspólnocie państw socjalistycznych, zjednoczeni we wspólnocie obronnej państw Układu Warszawskiego, stoimy na straży pokoju i socjalizmu. Najdobitniejszym dowodem tego, jak wierni jesteśmy tym ideom, jest fakt pospieszenia na pomoc narodom Czechosłowacji w obronie Ich i naszych interesów"; Archiwum Wojskowe w Oleśnicy (dalej: AWO), Zespół 874: 1 Batalion Szturmowy (dalej: Z-874: 1 bszt), 6415/16/1, Rozkaz specjalny dowódcy 1. bszt nr PF 2 z okazji 25-lecia Ludowego Wojska Polskiego, Hradec Králové, 12 X 1968 r., 544.

2 Na temat operacji „Dunaj”, a także działań polskich sił specjalnych zob. m.in.: Władysław Bułhak, „Kierunki badań nad udziałem Wojska Polskiego w operacji «Dunaj»,” w Aparat bezpieczeństwa, propaganda a praska wiosna - zbiór materiatów $z$ konferencji międzynarodowej, red. Maria M. Szwykowska-Rey (Praga: Ústav pro Studium Totalitních Režimů, 2009), 175-194; Krzysztof Gaj, „Wojsko Polskie w operacji «Dunaj»," w Wojny i konflikty zbrojne po 1945 roku. Zbiór studiów, t. 1, red. Mirosław Giętkowski i Łukasz Nadolski (Bydgoszcz: Muzeum Wojsk Lądowych, 2015), 67-98; Lech Kowalski, Kryptonim „Dunaj”: udział wojsk polskich w interwencji zbrojnej w Czechosłowacji w 1968 roku (Warszawa: Książka i Wiedza, 1992); Hubert Królikowski, 1. Batalion Szturmowy (Warszawa: Fundacja „Polonia Militaris”, 2007), 103-107; Leszek Pajórek, Polska a „Praska wiosna”. Udział wojska polskiego w interwencji zbrojnej w Czechosłowacji w 1968 roku (Warszawa: Egros, 1998); Radosław Szewczyk, „ «Pochmurne lato» i Operacja «Dunaj»," Odkrywca, nr 1 (2018), 48-54; Wokół Praskiej Wiosny. Polska i Czechosłowacja w 1968 roku, red. Łukasz Kamiński (Warszawa: Wyd. Instytutu Pamięci Narodowej, 2004).

3 Część tych materiałów zaprezentowano niedawno w: Szewczyk, „1 Batalion Szturmowy podczas przygotowań i interwencji w Czechosłowacji w 1968 r.," Przegląd Historyczno-Wojskowy 20, nr 3 (269) (2019): 158-177. 
bojowych w niektórych ich aspektach, co dobitnie ujawniło się w Czechosłowacji. Warto przy tym podkreślić, że 1 bszt był jednostką elitarną, co wiele mówiło o ówczesnej kondycji WP.

\section{Rola sił specjalnych w WP}

Koncepcje wykorzystania pododdziałów specjalnych zaczęto w WP rozwijać już na początku lat pięćdziesiątych, ${ }^{4}$ aczkolwiek widoczna intensyfikacja działań nastąpiła dopiero w kolejnej dekadzie. Była ona m.in. efektem prowadzenia szerokich studiów nad II wojną indochińską, ${ }^{5}$ jak również wynikała $\mathrm{z}$ nowych zadań, jakie po $1961 \mathrm{r}$. przewidziano dla WP w ramach Układu Warszawskiego (samodzielne operacje strategiczne na nadmorskim kierunku operacyjnym). Doświadczenia wynikające z konfliktów zbrojnych po 1945 r. wskazywały na potrzebę tworzenia oddziałów, które specjalizowałyby się w prowadzeniu działań pomocniczych względem wysiłku wielkich jednostek pancerno-zmechanizowanych, piechoty, artylerii oraz lotnictwa; realizując także zadania mające na celu oddziaływanie na morale wroga, jego logistykę oraz komunikację. ${ }^{6}$ Warto dodać, iż już wówczas

416 VII 1951 r. na mocy zarządzenia organizacyjnego Ministerstwa Obrony i Sztabu Generalnego dowódca Okręgu Wojskowego II rozpoczął formowanie 5 Samodzielnego Plutonu Rozpoznawczego przy 6 Batalionie Rozpoznawczym w Sztumie. W wrześniu 1954 r. rozpoczęto formowanie posiadającego m.in. dwie kompanie 19 Samodzielnego Batalionu Rozpoznawczego. Oddział ten 31 X 1961 r. przeformowano w 19 Batalion Powietrznodesantowy wchodzący w skład 6 Pomorskiej Dywizji Powietrznodesantowej (DPD). Tego samego dnia sformowano posiadający trzy kompanie 26 Batalion Rozpoznawczy (214 żołnierzy i 2 pracowników cywilnych), który chociaż podlegał operacyjnie 6 DPD, był przeznaczony do prowadzenia działań specjalnych. Na początku 1964 r. jednostka została wyłączona ze składu organizacyjnego 6 DPD i podporządkowana Głównemu Inspektoratowi Szkolenia Bojowego Ministerstwa Obrony Narodowej, a w kwietniu 1964 r. przeformowano ją na nowy etat, jako miejsce postoju wyznaczając Dziwnów. 8 V 1964 r. zmieniono nazwę jednostki na 1 Batalion Szturmowy. Królikowski, 1. Batalion Szturmowy, 11-25; AIPN, Biblioteka WSW oraz Zarządu II SG, 2603/2417, Tadeusz Limanowski, Wiesław Zajdziński, Użycie grup specjalnych w operacji zaczepnej frontu i armii. Zespołowa praca doktorska, cz. I, Warszawa 1988, 129-133.

5 Zob. np. Przemysław Benken, „Wojna wietnamska w latach 1966-1967 w zeszytach Sztabu Generalnego Wojska Polskiego," Studia z dziejów polskiej historiografii wojskowej 13, (2012): 109-122; Jerzy Maroń, „Konflikt w Wietnamie (1945-1975) w polskim piśmiennictwie historycznym. Kilka refleksji," w Biblioteka strategiczna, t. 1, red. Valentin Filip i Mirosław Nagielski, (Warszawa: Wyd. DiG, Bellerive-sur-Allier: Edition La Rama, 2017), 123-128.

6 Na temat genezy rozwoju jednostek specjalnych w WP po 1945 r. zob. np. Lech Wyszczelski, Działania nieregularne w myśli wojskowej i sztuce wojennej XIX i XX wieku (synteza) (Warszawa: Akademia Obrony Narodowej, 2001), 91-96. W 1986 r. 1 bszt scharakteryzowano następująco: „1. Batalion Szturmowy jest pododdziałem przeznaczonym do prowadzenia działań specjalnych na szczeblu wyższego związku operacyjnego. Organizacja i wyposażenie batalionu pozwala na prowadzenie skutecznego rozpoznania i dywersji na tyłach przeciwnika, a także w ograniczonym zakresie oddziaływania psychologicznego na ludność 
planowano, że 1 bszt będzie przysłowiową kuźnią kadr dla innych jednostek WP, jak również zamierzano go z czasem rozwinąć w pułk, czemu na przeszkodzie stawały jednak braki kadrowe i materialne. ${ }^{7}$

W programie szkolenia dla 1 bszt, opublikowanym w 1965 r., pisano o konieczności przygotowania żołnierzy do organizacji i prowadzenia działań dywersyjno-rozpoznawczych w ugrupowaniu nieprzyjaciela $\mathrm{w}$ początkowym okresie wojny, a także w toku rozwijających się operacji. Dowódcy poszczególnych grup specjalnych mieli się doskonalić w dowodzeniu w skomplikowanej sytuacji za linią frontu, a szczególną uwagę zwracać na skrytość działań, wzajemną pomoc i osobiste poświęcenie zwiadowców dla dobra realizowanej misji. Oficerom zalecano dbałość o stymulowanie rozwoju podwładnych na trzech głównych obszarach: walorów bojowych, politycznych i moralnych. ${ }^{8}$ Uzyskanie pożądanych efektów wiązano z odpowiednim doborem kadr - do jednostek specjalnych mogli trafić, po odbyciu dwuletniego przeszkolenia, jedynie „ludzie pochodzenia robotniczego i chłopskiego, członkowie partii i organizacji młodzieżowych, aktywiści społeczni bezgranicznie oddani sprawie realizowania polityki partii i rządu, o wysokim poczuciu odpowiedzialności za powierzone im zadania, o wysokich walorach psychiczno-moralnych, twardych i skrystalizowanych charakterach i wysokiej inteligencji”. ${ }^{9}$ Każdy kandydat musiał ponadto uzyskać akceptację ze strony organów bezpieczeństwa.

W procesie szkolenia żołnierza sił specjalnych wiele uwagi poświęcano na doskonalenie posiadanych umiejętności i nabywanie nowych w warunkach możliwie zbliżonych do rzeczywistych. Przykładowo we wspomnianym już programie szkolenia 1 bszt zapisano: „Dla pozoracji nieprzyjaciela

cywilną i wojska przeciwnika. [...] Batalion szturmowy, wykorzystując posiadane siły i środki, może skutecznie prowadzić działania specjalne na wszystkich rodzajach działań bojowych na głębokości zadania dalszego frontu, w dzień i w nocy, niezależnie od istniejących warunków atmosferycznych i terenowych, zarówno w warunkach użycia broni masowego rażenia, jak i bez jej użycia”. (AIPN, SWSW, 2386/33555, 1 Batalion Szturmowy - historia, zadanie, przeznaczenie, Warszawa, 24 IX 1986 r., 8-9).

AIPN, Zarząd II Sztabu Generalnego Wojska Polskiego w Warszawie (dalej: Zarząd II SG), 2602/8445, Zasadnicze przedsięwzięcia organizacyjne i szkoleniowe w zakresie działań specjalnych zrealizowane w 1967 r. oraz planowane na lata 1968-1970, b.m., 29 II 1968 r., 13-19.

8 AIPN, Biblioteka WSW oraz Zarządu II SG, 2603/8403, Program szkolenia dla 1. batalionu szturmowego, Warszawa 1965, 4.

9 AIPN, Zarząd II SG, 2602/8445, Pismo I zastępcy głównego inspektora szkolenia Inspektoratu Szkolenia Ministerstwa Obrony Narodowej gen. dyw. Tadeusza Tuczyńskiego do Zarządu II Sztabu Generalnego Wojska Polskiego, Warszawa, 18 I 1968 r., 2. Największym problemem było zebranie wystarczającej liczby żołnierzy z preferowanym średnim wykształceniem, których jeszcze na początku 1981 r. było jedynie 30\%. Ibid., 2602/15914, Pismo szefa Zarządu II SG WP płk. Eugeniusza Zajko do szefa Inspekcji Sił Zbrojnych WP na temat możliwości prowadzenia działań specjalnych, Warszawa, 5 II 1981 r., 50. 
nie stosować tarcz, lecz żołnierzy, a w przypadku, gdzie należy obezwładnić nieprzyjaciela przy pomocy rzutu nożem lub granatem, stosować manekiny, wykorzystując do tego celu stare mundury. [...] We wszystkich ćwiczeniach taktycznych stosować realną ochronę obiektów i stawiać zadania obezwładnienia (likwidacji) wartownika". ${ }^{10}$

1 bszt miał swoje zadania wykonywać, wydzielając małe patrole, grupy oraz zespoły grup specjalnych działające na tyłach przeciwnika. Ich przerzut za linię frontu dokonywać się miał drogą lądową (przenikanie) - pieszo lub środkami transportowymi; morską - przy pomocy okrętów podwodnych, kutrów desantowych itp.; a także powietrzną - przy pomocy samolotów transportowych lub śmigłowców. Uwzględniano również prowadzenie przez dane grupy specjalne działań „obronnych”, po pozostawieniu ich na terenie przewidywanym do czasowego zajęcia przez nieprzyjaciela. ${ }^{11}$ Co godne odnotowania, żołnierzy sił specjalnych przygotowywano wyłącznie do działań w Europie Zachodniej i nie otrzymywali oni zbyt wiele informacji dotyczących „armii sojuszniczych”, co w realiach wydarzeń, do których doszło w 1968 r., okazało się poważnym zaniedbaniem.

\section{Przygotowania do interwencji}

24 lipca 1968 r. do garnizonu 1 bszt w Dziwnowie przybył przedstawiciel Inspektoratu Szkolenia Ministerstwa Obrony Narodowej. Jak pisał następnie w sprawozdaniu z przebiegu ćwiczeń „Pochmurne Lato” dowódca batalio$\mathrm{nu}$, ppłk. Tadeusz Wandzel ${ }^{12}$, wprowadzono $\mathrm{w}$ jednostce stan podwyższonej

10 Ibid., 2603/8403, Program szkolenia dla 1. batalionu szturmowego, Warszawa 1965, 23.

11 AIPN, SWSW, 2386/33555, 1. Batalion Szturmowy - historia, zadanie, przeznaczenie, Warszawa, 24 IX 1986 r., 8.

12 Tadeusz Wandzel (ur. 1931 - zm. 1970) - był z wykształcenia ślusarzem, a przed wstąpieniem do WP w 1949 r. pracował jako robotnik. Początkowo skierowano go do Oficerskiej Szkoły Artylerii w Toruniu, którą ukończył w 1951 r. Następnie służył kolejno w różnych jednostkach artylerii jako dowódca baterii lub osoba odpowiedzialna za kwestie szkoleniowe: w latach 1951-1952 przydzielono go do 118 Pułku Artylerii Ciężkiej, w latach 1952-1955 do Ośrodka Artylerii nr 1, w latach 1955-1957 do 14 Dywizjonu Artylerii Rakietowej, w latach 1957-1959 do 19 Dywizjonu Artylerii Rakietowej, a w latach 1959-1960 do 5 Dywizjonu Artylerii 6 DPD. Na początku lat sześćdziesiątych, po odbyciu odpowiedniego przeszkolenia, Wandzel - jako wyróżniający się oficer - został żołnierzem wojsk powietrznodesantowych, obejmując w 1961 r. funkcję zastępcy dowódcy ds. liniowych w 16 Batalionie Powietrznodesantowym z 6 DPD. W 1964 r. skierowano go na studia do Akademii Sztabu Generalnego, po ukończeniu której w 1967 r. mianowano go dowódcą 1 bszt. Wandzel zginął tragicznie 14 VII 1970 r. podczas wykonywania skoku spadochronowego. Zob. Centralne Archiwum Wojskowe Wojskowego Biura Historycznego (dalej: CAW-WBH), Kolekcja Teczek Akt Personalnych (dalej: TAP), 1562/74/452. Jeden z podwładnych ppłk. Wandzela wspomniał go następująco: „Wspaniały dowódca, wychowawca, tryskający energią, z ogromnym zasobem wiedzy wojskowej i ogólnej [...] Z wielkim zapałem przystąpił do realizacji programu 
gotowości i „wyjaśniono dowództwu [batalionu] charakter ewentualnych przyszłych działań oraz potrzebę prowadzenia pracy wychowawczej wśród żołnierzy w związku z rozwojem sytuacji w Czechosłowacji”. ${ }^{13} \mathrm{~W}$ dniach 24-26 lipca trwało przygotowywanie pojazdów i sprzętu 1 bszt do transportu na południe. Nie zaniedbywano także działań politycznych, jak również przeprowadzono selekcję żołnierzy, którzy mieli wziąć udział w „ćwiczeniach". 26 lipca 1 bszt otrzymał rozkaz, by transportem kolejowym przemieścić do Świdnicy Śląskiej wytypowane pododdziały, co nastąpiło w dniach 28-29 lipca. Garnizon w Dziwnowie opuściły: dwie kompanie specjalne, kompania specjalna płetwonurków, kompania rozpoznawcza, kompania łączności, pluton gospodarczy i pluton transportowy. Ich stan osobowy wynosił: 36 oficerów, 25 podoficerów i 230 szeregowych. ${ }^{14}$ Jak pisał Lech Wyszczelski, z 4 pododdziałów bojowych 1 bszt można było utworzyć 12 grup specjalnych (szturmowych), 6 grup rozpoznawczych oraz 6 grup specjalnych płetwonurków. ${ }^{15}$ Składy poszczególnych grup bywały jednak zróżnicowane. Przykładowo w przypadku 1 Kompanii Specjalnej liczyły one 7 osób, natomiast w 2 Kompanii Specjalnej było ich 9-10. Wynikało to z nieco odmiennej struktury organizacyjnej. Grupa specjalna płetwonurków, mająca prowadzić rozpoznanie w środowisku wodnym, składała się z 10 żołnierzy. Kompaniom specjalnym przed rozpoczęciem działań przydzielano radiotelegrafistów z plutonu radiostacji krótkofalowych R-350 należącego do kompanii łączności. Łączność z poszczególnymi grupami zapewniał zaś pluton radiostacji krótkofalowych dużej i średniej mocy dysponujący radiostacjami typu R-830 i R-118. Kompania rozpoznawcza, będąca samodzielnym pododdziałem w ramach 1 bszt, wydzielała siedmioosobowe grupy specjalne. Posiadała ponadto w swoim składzie pluton łączności radiowej, dzięki

szkoleniowego kadry i zwiadowców wprowadzając nowe, ciekawe metody" cyt. za: Królikowski, 1. Batalion Szturmowy, 33.

13 AIPN, Zarząd II SG, 2602/8445, Sprawozdanie z działań 1. bszt na ćwiczeniach „Pochmurne Lato", b.m., 30 VIII 1968 r., 78.

14 Stan osobowy 1 bszt po reorganizacji z 1967 r. przedstawiał się następująco: 351 żołnierzy i 4 pracowników cywilnych. Królikowski, 1. Batalion Szturmowy, 34; AIPN, Biblioteka WSW oraz Zarządu II SG, 2603/2417, Tadeusz Limanowski, Wiesław Zajdziński, „Użycie grup specjalnych w operacji zaczepnej frontu i armii”. Zespołowa praca doktorska, cz. I, Warszawa 1988, 134. Sławomir Sadowski oceniał, iż użycie 1 bszt w Czechosłowacji wynikało z faktu, iż niedawno sformowana 62 kompania specjalna funkcjonująca w ramach Śląskiego Okręgu Wojskowego nie osiągnęła pełnej gotowości do działań, przez co nie dysponowano pododdziałem specjalnym. To też miało być przyczyną nie zawsze właściwego wykorzystania 1 bszt, który przed interwencją w Czechosłowacji był przygotowywany do nieco innych działań aniżeli armijna kompania specjalna. Sławomir Sadowski, „Powstanie, zasady działania i szkolenia jednostek specjalnych w Ludowym Wojsku Polskim," Bezpieczeństwo. Teoria i praktyka 10, nr 3 (2016): 164.

15 Tak duży komponent płetwonurków wiązał się ze wspomnianymi już planami prowadzenia przez WP samodzielnych operacji strategicznych na nadmorskim kierunku operacyjnym. 
czemu mogła zorganizować własne centrum odbiorcze do utrzymywania łączności z poszczególnymi grupami. ${ }^{16}$

W transporcie do Świdnicy Śl. znalazło się: 20 samochodów ciężarowych, 17 specjalnych, 3 osobowo-terenowe, 2 motocykle, 7 przyczep, 38 radiostacji, materiały wybuchowe ( $860 \mathrm{~kg}$ trotylu i $736 \mathrm{~kg}$ plastyku), po 200 spadochronów głównych i zapasowych, materiały wybuchowe oraz 2 jednostki ognia. Żołnierze 1 bszt uzbrojeni byli w 14 ręcznych karabinów maszynowych RPD, 194 karabinki AK-47, 17 karabinów-granatników wz. 1960 (AK-GN; był to AK-47 przystosowany do wystrzeliwania granatów nasadkowych), 15 granatników przeciwpancernych RPG-7, 60 pistoletów P-64 i 155 pistoletów TT wz. 33. ${ }^{17}$

Obawiano się, że na obszarze Czechosłowacji może dojść do walki z ludnością cywilną ${ }^{18}$, brano również pod uwagę możliwość interwencji wojsk NATO, a zwłaszcza Republiki Federalnej Niemiec, ${ }^{19}$ aczkolwiek to ostanie zagrożenie było instrumentalnie wykorzystywane przez własną propagandę w celu uzasadnienia konieczności interwencji. Dobrym tego przykładem mogła być wypowiedź jednego z żołnierzy WP opublikowana przez korespondentów Żołnierza Wolności: „Już raz wyszedł na Polskę najazd z terenu Czechosłowacji przez hordy faszystowskie i nie można teraz dopuścić do tego, aby znowu imperialiści próbowali otoczyć nasz kraj, obalając ustrój socjalistyczny w Czechosłowacji”. ${ }^{20}$

\footnotetext{
16 Wyszczelski, Działania nieregularne, 94. Zob. Pajórek, Polska a „Praska wiosna”, 117.

17 AWO, Z-874: 1 bszt, 6415/16/1, Meldunek dowódcy 1. bszt ppłk. Tadeusza Wandzela o stanie bojowym 1. bszt, b.m., 31 VII 1968 r., 1. Co ciekawe, na potrzeby ćwiczeń „Pochmurne Lato" zabrano również 30 kompletów aparatów do nurkowania dla kompanii płetwonurków.
}

18 AIPN, Zarząd II SG, 2602/8445, Sprawozdanie z organizacji i przebiegu działań organów rozpoznania i sił specjalnych w operacji „Dunaj”, Warszawa 1968, 2. Jak wspomniał Władysław Jandeczko, jeden $\mathrm{z}$ weteranów 62 Armijnej Kompanii Specjalnej, którą również skierowano do Czechosłowacji, żołnierze rozważali nie tylko konfrontację z siłami NATO, lecz również brali pod uwagę możliwość oporu ze strony czechosłowackiej: „Spodziewaliśmy się jakiejś reakcji ze strony Czeskiej Armii Ludowej. Mieliśmy ostrą amunicję i granaty. Znaliśmy regulamin i nikt nie musiał mówić, że możemy strzelać.... Gdyby do mnie strzelano, też strzelałbym. Ale okazało się, że na ćwiczeniach w Polsce nasi żołnierze bardziej dostawali w dupę niż na tej wojnie". Cyt. za: Jarosław Rybak, Commando: nieznana historia 62. Kompanii Specjalnej Wojska Polskiego (Warszawa: Wyd. Creatio PR, 2017), 35-36.

19 Zob. np. Archiwum Akt Nowych (dalej: AAN), Komitet Centralny Polskiej Zjednoczonej Partii Robotniczej (dalej: KC PZPR), Wydział Zagraniczny, LXXVI-727, Zapis wystąpień na spotkaniu pierwszych sekretarzy komitetów centralnych komunistycznych partii Bułgarii, Niemieckiej Republiki Demokratycznej, Polski, Związku Socjalistycznych Republik Radzieckich i Węgier w Moskwie w związku z sytuacją w Czechosłowacji, Moskwa, 8 V 1968 r., 83 i n.

20 Cyt. za: Czesław Goliszewski i Henryk Kacała, „Wysłannicy «Żołnierza Wolności» donoszą z Czechosłowacji," Kurier Szczeciński, sierpień 23-24, 1968. 
30 lipca ze sztabu 2 Armii WP nadszedł rozkaz, by 1 Kompanię Specjalną przekazać do dyspozycji dowódcy 11 Dywizji Pancernej, a 2 Kompanię Specjalną - do dyspozycji dowódcy 10 Dywizji Pancernej. 1 Kompania miała w swym składzie 4 oficerów, podoficera i 41 szeregowców; 2 Kompania zaś - 5 oficerów, podoficera i 39 żołnierzy. ${ }^{21}$ Reszta 1 bszt (dowództwo i sztab, kompania łączności, kompania rozpoznawcza, kompania płetwonurków, pluton transportowy i pluton gospodarczy) otrzymała polecenie przegrupowania się na lotnisko Pszenno, gdzie stacjonował 49 Pułk Śmigłowców mający do dyspozycji 11 śmigłowców typu Mi-2, 6 typu Mi-4 i 3 typu Mi-8. ${ }^{22}$ Tam z pozostawionych dowódcy 1 bszt sił i środków zorganizowano: zespół dowodzenia, dowództwo batalionu oraz 9 grup specjalnych w składzie $1+7$ (dowódca i 7 żołnierzy).

Po wydzieleniu 1 i 2 Kompanii do wsparcia dywizji pancernych (18 sierpnia kompanie przybyły w rejon zgrupowania batalionu, które ponownie opuściły 19-20 sierpnia) z reszty 1 bszt utworzono „odwód specjalny”, początkowo nie przewidując dla niego adekwatnego zastosowania. Wskazywało to, iż sztab 2 Armii początkowo nie potrafił właściwie wykorzystać przydzielonych mu elitarnych żołnierzy. W powstałym po zakończeniu operacji sprawozdaniu z działań rozpoznania i sił specjalnych stwierdzono: „Planu działań specjalnych nie opracowano, a pododdziałom specjalnym, którymi dysponowała armia, nie postawiono żadnych zadań". ${ }^{23}$

Sytuacja powyższa uległa zmianie dopiero po przybyciu do sztabu 2 Armii oficerów Zarządu II SG WP. Wstępne kategorie zadań dla jednostek 1 bszt sztab 2 Armii określił następująco:

${ }^{21}$ AWO, Z-874: 1 bszt, 6415/16/1, Meldunek operacyjny 1 bszt, b.m., 13 VIII 1968 r., 18. Zob. ibid., Meldunek operacyjny 1 bszt, b.m., 20 VIII 1968 r., 32. W dokumencie tym liczebność kompanii oddelegowanych do dywizji pancernych była nieco inna (1 kompania: 3 oficerów, podoficer i 40 szeregowców; 2 kompania: 2 oficerów, podoficer i 42 szeregowców). Ponadto każda $\mathrm{z}$ kompanii zabrała ze sobą po trzy samochody i motocykl.

22 AIPN, Zarząd II SG, 2602/8445, Sprawozdanie z organizacji i przebiegu działań organów rozpoznania i sił specjalnych w operacji „Dunaj”, Warszawa 1968, 4. Dni poprzedzające wkroczenie do Czechosłowacji polscy żołnierze poświęcali m.in. na doskonalenie współpracy z pilotami śmigłowców Mi-8. Ćwiczono loty na bardzo małych wysokościach i desantowanie się z helikopterów. Rybak, „Czeska wojna,” Polityka, sierpień 28, 2010, 58. Dowódca Zgrupowania Lotniczego 2 Armii, ppłk Jerzy Knyszewski, stwierdził po latach, że „bliskie sąsiedztwo pozwoliło nam wzajemnie poznać się, co rzutowało później na poziom wykonywanych wspólnie zadań. Żołnierze tego batalionu [1 bszt] byli wszechstronnie wyszkoleni, o wyjątkowej sprawności fizycznej. Ich sąsiedztwo wpływało korzystnie na morale moich ludzi, a poza tym stanowili świetną obstawę ochronno-prewencyjną całego zgrupowania”. Kowalski, Kryptonim „Dunaj”, 109.

23 AIPN, Zarząd II SG, 2602/8445, Sprawozdanie z organizacji i przebiegu działań organów rozpoznania i sił specjalnych w operacji „Dunaj”, Warszawa 1968, 4, 7. 
- opanowanie i obrona mostu do chwili podejścia wojsk własnych;

- opanowanie sieci telewizyjnych i rozgłośni radiowych;

- opanowanie węzłów dróg;

- opanowanie i utrzymanie odcinków dróg na przełęczach górskich;

- opanowanie strażnic;

- rozpoznanie lotniska i współdziałanie w celu jego opanowania;

- rozpoznanie za przegrupowującymi się wojskami.

Kompanie specjalne nr 1 i 2 otrzymały zadania polegające na: (1) uchwyceniu w strefie granicznej obiektów wojskowych i umożliwieniu rozwinięcia działań dla awangard dywizji pierwszego rzutu (pododdziały miały wydzielić po 2 patrole w składzie $1+12$, tzw. grupy szturmowo-torujące, którym przydzielono wsparcie w postaci transporterów opancerzonych piechoty zmechanizowanej); (2) rozwijaniu działań na głębokości do $25 \mathrm{~km}$ w głąb Czechosłowacji w celu opanowania: radiostacji, węzłów dróg, trudnych przejść górskich, mostów itp., a następnie, po wykonaniu tych zadań, przejście do odwodu armii. ${ }^{24}$

„Odwód specjalny” miał być w gotowości do działań w trzech rzutach na głębokości 20-50 km przed maszerującymi kolumnami dywizji pancernych. Powierzono mu zadanie opanowania i utrzymania najważniejszych węzłów dróg i obiektów komunikacyjnych, rozpoznania i opanowania lotnisk oraz rozgłośni radiowych i telewizyjnych, jak również meldowania o przegrupowaniach jednostek czechosłowackich i terenie działań. ${ }^{25}$

Jak wynikało z powyższego, jednostkom specjalnym, oprócz torowania drogi dywizjom pancernym, postawiono zadanie eliminowania „ośrodków dywersji ideologicznej" - czyli radiostacji, które nadawały programy pełne „wrogich treści”. Korespondenci „Żołnierza Wolności” po rozpoczęciu operacji „Dunaj” scharakteryzowali ich aktywność następująco: „środki masowego przekazu wzmagają oszczercze ataki, nawołują do chaosu i rozprężenia. [...] W tym samym dniu, w którym byliśmy w Czechosłowacji, radiostacja nadała prowokacyjną informację, jakoby nasi żołnierze zranili fotoreportera fotografującego polską kolumnę wojskową. [...] Nasi specjaliści-łącznościowcy mówią: [«]System [...] radiostacji wskazuje, że sieć ta była zorganizowana już o wiele wcześniej. [...] [»] Do czego więc zmierzały te przygotowania [?]”.".

24 Ibid., Sprawozdanie z działań 1. bszt na ćwiczeniach „Pochmurne Lato”, b.m., 30 VIII 1968 r., 79.

25 Ibid., 2602/8445, Sprawozdanie z organizacji i przebiegu działań organów rozpoznania i sił specjalnych w operacji „Dunaj”, Warszawa 1968, 8.

26 Goliszewski i Kacała, „Wysłannicy «Żołnierza Wolności» donoszą z Czechosłowacji: Na kursie Góry Stołowe, Kurier Szczeciński, sierpień 25, 1968. Zob. też: „Wydarzenia w Czechosłowacji," Żotnierz Polski, nr 35 (1968): 2. 
Przed unieszkodliwieniem radiostacji należało je najpierw zlokalizować - pierwotnie przygotowywano je, podobnie jak wiele magazynów z bronią, do wykorzystania w przypadku ataku NATO na Czechosłowację i ich umiejscowienie było tajne. Zadanie wskazania celu dla jednostek specjalnych otrzymał m.in. Wydział Analityczno-Informacyjny 2 Ośrodka Rozpoznania Radioelektronicznego w Przasnyszu, który namierzył 29 obiektów. Jak pisał w sprawozdaniu jego dowódca, płk Lesław Klisowski: „przeprowadzony nasłuch oraz rozpoznanie radiowe stwierdziło, że na terenie Czechosłowacji pracowały nielegalnie rozgłośnie i radiostacje wchodzące w podziemną sieć propagandową elementów kontrrewolucyjnych, które rozwijały i wzmagały akcję wymierzoną przeciwko władzy ludowej w Czechosłowacji. Rozgłośnie te w swoich 24-godzinnych programach nadawały audycje, komunikaty propagandowe, które godziły w ustrój socjalistyczny, a w szczególności w Związek Radziecki. Komunikaty te były nadawane, oprócz czeskiego, w językach: rosyjskim, niemieckim, polskim, węgierskim, francuskim angielskim i włoskim". ${ }^{27}$

Namierzaniem „nielegalnych” radiostacji zajmował się także 11 Batalion Rozpoznania Radioelektronicznego, który 3 sierpnia rozwinął się na rubieży Krzeszów-Kamienna Góra-Lubawka, a następnie 23 sierpnia został przegrupowany do dalszych działań na terenie Czechosłowacji, lecz podjął je dopiero dwa dni później. Batalion namierzył 33 obiekty. Jak zapisano w sprawozdaniu z działań tej jednostki, „oprócz stałych rozgłośni pracowały również radiostacje koczujące zakresu UKF [fale ultrakrótkie] nadające również programy o charakterze dywersyjno-politycznym". ${ }^{28}$ Zadanie wykrywania radiostacji otrzymał także 7 Pułk Radioelektroniczny Wojskowej Służby Wewnętrznejej ${ }^{29}$ i Samodzielny Wydział Radiokontrwywiadu

27 AIPN, Zarząd II SG, 2602/8445, Sprawozdanie dotyczące pracy fonicznych nielegalnych radiostacji działających w Czechosłowacji za okres 22 VIII-11 IX 1968 r., Warszawa, b.d., 50. Zob. też: Paweł Piotrowski, „W nocy z wtorku na środę, Biuletyn Instytutu Pamięci Narodowej, styczeń, nr 8-9 (2003): 58-59.

28 AIPN, Zarząd II SG, 2602/8445. Notatka dotycząca pracy 11. Batalionu Rozpoznania Radioelektronicznego na terenie Czechosłowacji, b.m., 30 IX 1968 r., 90.

29 Piotrowski, „Udział Wojska Polskiego w interwencji w Czechosłowacji,” w Wokót, 103. Ponadto 24 VIII 1968 r. szef WSW otrzymał ze SG WP polecenie skierowania do dyspozycji 2 Armii w Hradec Králové 10 grup do wykrywania i unieruchamiania radiostacji, drukarń i innych środków masowego przekazu. W skład grup mieli wejść specjaliści od rozpoznania, demontażu urządzeń i ochrony. AIPN, Zarząd II SG, 2602/20041, Pismo szefa SG WP gen. dyw. Bolesława Chochy do szefa WSW gen. bryg. Teodora Kufla, Warszawa, 24 VIII 1968 r., 71; Zbiór dokumentów dotyczących Układu Warszawskiego (dalej: Dokumenty UW), 02958/27, Sposób wykorzystania oraz działanie pododdziałów rozpoznawczych 2. Armii w ćwiczeniach „Pochmurne Lato” i „Dunaj”, b.m., 1 X 1968 r., 178. 
Ministerstwa Spraw Wewnętrznych. ${ }^{30}$ To właśnie tzw. działania na radiostacje miały stać się najbardziej spektakularnymi i znanymi misjami wykonywanymi przez polskie jednostki specjalne w sierpniu 1968 r. Tymczasem, jak pisał w swoim sprawozdaniu ppłk Wandzel, przygotowując swój batalion do wkroczenia na terytorium południowego sąsiada, „w pracy wychowawczej w dalszym ciągu informowano cały stan osobowy o rozwoju sytuacji w Czechosłowacji oraz wyjaśniono nieodzowną potrzebę udzielenia pomocy bratnim narodom Czechosłowacji”."

Podsumowując przegrupowanie do działań na terenie Czechosłowacji, należałoby stwierdzić, że sztab 2 Armii nie uwzględnił pełnych możliwości, jakie dawało mu posiadanie etatowych i przydzielonych sił specjalnych, jak również nie wyodrębnił osobnej komórki odpowiedzialnej za kierowanie siłami specjalnymi. Największym błędem było rozdzielenie pododdziałów sił specjalnych, które nierzadko wykorzystywano niezgodnie z przeznaczeniem i ich szczególnymi w skali armii możliwościami (m.in. 62 Armijną Kompanię Specjalną angażowano przede wszystkim do obrony sztabu armii). ${ }^{32}$ Nie były to wszakże wszystkie niedociągnięcia. Wiele kolejnych miało się pojawić już w trakcie prowadzenia działań.

Jarosław Rybak w artykule opublikowanym w 2010 r. w tygodniku Polityka, powołując się na relacje weteranów 1 bszt, pisał o tym, że grupy specjalne przeniknęły do Czechosłowacji przy pomocy śmigłowców kilka dni przed rozpoczęciem operacji „Dunaj”. ${ }^{33}$ Informacje te nie znalazły potwierdzenia w dokumentach, do których dotarł autor, aczkolwiek w monografii 1 bszt autorstwa Huberta Królikowskiego pisano o tym, iż na kilka dni przed wkroczeniem do Czechosłowacji trzy śmigłowce Mi-8 z grupami specjalnymi na pokładzie zostały zmuszone do wylądowania na terytorium południowego sąsiada PRL wskutek nieprzewidzianej zmiany warunków atmosferycznych. Ubezpieczywszy pozycje, Polacy pozostali w Czechosłowacji do świtu następnego dnia. ${ }^{34}$ Wynikało z tego, że żołnierze 1 bszt przekroczyli granicę jeszcze przed rozpoczęciem operacji „Dunaj”, jednakże nastąpiło to przypadkowo.

\footnotetext{
30 Grzegorz Majchrzak, „Operacja «Podhale», w Wokót, 111. Zob. też: Jarosław Neja, „Przed żołnierzami wkroczyli agenci,” Biuletyn Instytutu Pamięci Narodowej, nr 8/9 (2003): 65-69.

31 AIPN, Zarząd II SG, 2602/8445, Sprawozdanie z działań 1. bszt na ćwiczeniach „Pochmurne Lato", b.m., 30 VIII 1968 r., 79.

32 Ibid., Sprawozdanie z organizacji i przebiegu działań organów rozpoznania i sił specjalnych w operacji „Dunaj”, Warszawa 1968, 9-10.

33 Rybak, „Czeska wojna, 57.

34 Królikowski, 1. Batalion Szturmowy, 104.
} 


\section{Operacja „Dunaj”}

Jak zapisano w sprawozdaniu z działań rozpoznania i sił specjalnych, 1 i 2 kompanie specjalne 20 sierpnia na krótko przed północą ${ }^{35}$ „rozpoczęły swe działania planowo, jednak z uwagi na nienapotykanie oporu ze strony jednostek czechosłowackich rozwijały działania głębiej [niż przewidywano] i do końca operacji pozostały w czołowych elementach ugrupowania wojsk pierwszego rzutu" ${ }^{36}$ Aktywności tych dwóch pododdziałów, które zajęły czechosłowackie palcówki graniczne i rozbroiły ich obsadę, nie poświęcano już w dokumentach większej uwagi, skupiając się na analizie dokonań „odwodu specjalnego", aczkolwiek przykładowo w sprawozdaniu z działalności pododdziałów rozpoznawczych 11 Dywizji Pancernej zapisano, że grupa nr 1 z przydzielonej do dywizji kompani specjalnej uchwyciła punk graniczny w miejscowości Lubawka, posterunek milicji w miejscowości Bernartice oraz radiostację w miejscowości Trutnov; natomiast grupa nr 2 opanowała punkt graniczny w miejscowości Mieroszów i most w rejonie miejscowości Meziměstí. ${ }^{37}$

Czechosłowackie „nielegalne rozgłośnie” szybko zareagowały na przekroczenie granicy przez polskie oddziały. Jak wspomniał gen. bryg. Włodzimierz Sawczuk, zastępca dowódcy 2 Armii ds. politycznych: „Rozgłośnie z różnym stopniem wrogości poczęły pobudzać ludność i nawoływać do oporu. To znalazło oddźwięk natychmiastowy. Za ich pomocą próbowano również oddziaływać na nasze wojska, adresując specjalne audycje radiowe «do żołnierzy LWP»". 38

Treść przykładowej audycji w języku polskim do żołnierzy WP wkraczających do Czechosłowacji zacytował w swoim opracowaniu Leszek Pajórek: „Odezwa do polskich żołnierzy. Protestujemy przeciwko okupacji naszego państwa, w której uczestniczą wasze siły zbrojne. Tym gwałtem i niczym nieusprawiedliwionym aktem przerywacie i niszczycie te sojusznicze

\footnotetext{
35 O godzinie 23:50.

36 AIPN, Zarząd II SG, 2602/8445, Sprawozdanie z organizacji i przebiegu działań organów rozpoznania i sił specjalnych w operacji „Dunaj”, Warszawa 1968, 9-10, 14.

37 AIPN, Dokumenty UW, 02958/27, Sprawozdanie szefa Wydziału Rozpoznawczego i szefa sztabu 11. Dywizji Pancernej z działalności pododdziałów rozpoznawczych 11. Dywizji Pancernej, Hradec Králové, 3 IX 1968 r., 40. Ponadto Hubert Królikowski pisał, że komandosi przydzieleni do 10 Dywizji Pancernej wykryli czechosłowacki zespół rozpoznawczy, który rozpoznawał ugrupowanie 25 Pułku Zmechanizowanego. Królikowski, 1 Batalion Szturmo$w y, 105$.

38 Kowalski, Kryptonim „Dunaj”, 65. Opór ludności cywilnej przejawiał się przede wszystkim we wznoszeniu barykad na trasach przemarszu jednostek 2 Armii i przestawianiu znaków drogowych. Okoliczni mieszkańcy próbowali również powstrzymywać ruch polskich kolumn, kładąc się na drodze.
} 
związki między naszymi narodami, które powstały w walce przeciwko faszyzmowi i imperializmowi i w walce o socjalizm. Jest jeszcze czas, by naprawić dzisiejszy fatalny błąd, by nie powstała $\mathrm{z}$ tego największa tragedia naszych narodów, by nie niszczyć na wszelkie czasy przyjaźni naszych narodów. Apelujemy do was o opuszczenie terytorium naszego państwa przez wasze siły zbrojne. Pozostawcie naszym narodom możliwość swobodnego i demokratycznego decydowania o swoim bycie". ${ }^{39}$

21 sierpnia 1 bszt otrzymał rozkaz opanowania stacji przekaźnikowej Chloumek koło Mělníka. ${ }^{40}$ Zadanie wykonano, angażując do tego sześć grup specjalnych, które przerzucono w rejon radiostacji śmigłowcami Mi-8. Radiostacja została opanowana w ciągu około 20 minut po wylądowaniu, przy czym misją dowodził osobiście ppłk Wandzel. Pomimo sukcesu, już wówczas ujawnił się problem, którego nie zdołano rozwiązać w toku operacji „Dunaj”. Piloci polskich śmigłowców nie otrzymali zezwoleń na wykonywanie lotów nocnych i w warunkach ograniczonej widoczności, „choć na pewno mogło to przynieść znaczne efekty natury psychologicznej i bojowej" ${ }^{41}$. Wprawdzie posiadali odpowiednie uprawnienia do wykonywania tego rodzaju zadań, ale nie mogli lądować z grupami specjalnymi bez wcześniejszego oznaczenia lądowiska i naprowadzania z ziemi. Tym sposobem działalność „odwodu specjalnego” została uzależniona od pory dnia i pogody. Noc i złe warunki atmosferyczne ograniczyły możliwość użycia grup specjalnych $w$ pierwszych godzinach operacji. Te same przyczyny doprowadziły do tego, że choć przerzutu śmigłowcami Mi-8 dokonano o godz. 17:50, to powrót zaangażowanych sił nastąpił, z uwagi na złą pogodę, dopiero 22 sierpnia o godz. 9:40, gdyż Mi-8 nie mogły latać $\mathrm{w}$ chmurach $^{42}$

39 Cyt. za: Pajórek, Polska a „Praska wiosna”, 136. Warto dodać, że w audycjach występowali także przedstawiciele polskiej mniejszości narodowej w Czechosłowacji, którzy w zdecydowanej większości opowiedzieli się przeciwko interwencji wojsk Układu Warszawskiego; zob. Anna Szczepańska, „Sytuacja Polaków w Czechosłowacji w latach 1956-1968,” w Między ideologia a socjotechniką. Kwestia mniejszości narodowych $w$ działalności władz komunistycznych - doświadczenie polskie i środkowoeuropejskie, red. Maria Semczyszyn i Jarosław Syrnyk (Warszawa-Szczecin-Wrocław: Wyd. Instytutu Pamięci Narodowej, 2014), 79.

40 W dokumentach podano, że stacja była położona kilometr na wschód od miejscowości Liběchov; zob. Szewczyk, „1 Batalion Szturmowy,” 164.

41 AIPN, Zarząd II SG, 2602/8445, Sprawozdanie z organizacji i przebiegu działań organów rozpoznania i sił specjalnych w operacji „Dunaj”, Warszawa 1968, 10.

42 Dramatyczny opis lotu śmigłowcem z Częstochowy do Czechosłowacji w trudnych warunkach pogodowych zawarto w: Goliszewski, „Wśród ofiarnych i odważnych ludzi,” Żotnierz Wolności, sierpień 30, 1968. Chociaż intencją autora artykułu było niewątpliwie zaprezentowanie profesjonalizmu polskich pilotów i przebywających na pokładzie śmigłowca oficerów WP, to jednak ujawniał w nim również braki w oprzyrządowaniu, które umożliwiałyby bezpieczny lot w warunkach bardzo ograniczonej widoczności. 
(piloci śmigłowców Mi-4 nie mieli takich ograniczeń). ${ }^{43}$ Jakby tego było mało - w akcji wzięło udział 72 żołnierzy (cały „odwód specjalny”), w tym dowództwo 1 bszt i szef Oddziału Rozpoznawczego 2 Armii. Po zakończeniu operacji „Dunaj” takie przeprowadzenie misji oceniono bardzo krytycznie, gdyż 2 Armia utraciła w rezultacie na pewien czas możliwość koordynowania działań grup specjalnych. Ponadto „dla stworzenia tej grupy użyto całość sił batalionu bez pozostawiania jakiegokolwiek odwodu dla ewentualnego wykonania innych zadań, jakie wyniknąć mogły przed czasem powrotu grupy działającej na radiostacje". ${ }^{44}$

$\mathrm{W}$ jednym $\mathrm{z}$ opracowań poświęconych wnioskom taktycznym i propozycjom szkoleniowym dla jednostek specjalnych stwierdzono: ,jedynie brak doświadczenia mógł tłumaczyć fakt, że obok zaangażowania tak dużego składu grupy do akcji włączył się osobiście zarówno szef Oddziału Rozpoznawczego armii, jak i dowódca batalionu szturmowego. Prawdą jest, że wyższy dowódca obowiązany jest dawać podwładnym osobisty przykład odwagi i zaangażowania, ale brawura na miarę Somosierry dla całokształtu działań zbędna i niczym nieuzasadniona"."

Zarówno w toku pierwszej, jak i kolejnych akcji wystąpiły także poważne trudności wynikające z braku przygotowania Polaków do unieszkodliwiania urządzeń radiowych ( $w$ składzie poszczególnych grup nie było elektroenergetyków ani radiowców). Skutkowało to tym, iż radiostacje po wycofaniu się jednostek specjalnych nierzadko wznawiały nadawanie „wrogich treści”. ${ }^{46}$ Prócz nieobecności wspomnianych specjalistów dawały się we znaki

43 Jeden $\mathrm{z}$ żołnierzy 1 bszt biorący udział w „akcjach na radiostacje”, sierż. sztab. Janusz Tomczak, wspomniał to zdarzenie następująco: „Bez problemu wylądowaliśmy, opanowaliśmy obiekt i zarekwirowaliśmy panele nadawcze. Ale przyszła taka mgła, że lotnicy nie zdecydowali się na powrót. Na ściernisku czekaliśmy na atak”. Cyt. za: Rybak, „Czeska wojna,” 58.

44 AIPN, Zarząd II SG, 2602/8445, Sprawozdanie z organizacji i przebiegu działań organów rozpoznania i sił specjalnych w operacji „Dunaj”, Warszawa 1968, 15.

45 Ibid., Wnioski taktyczne i propozycje szkoleniowe w świetle działań specjalnych prowadzonych w operacji „Dunaj”, Warszawa 1968, 13-14. „Osobisty udział w akcji: dowódcy batalionu, szefa łączności i większości oficerów z grupy dowodzenia działaniami specjalnymi, uzasadniony w konkretnym przypadku wykonywania pierwszego zadania (podniesienie stanu moralnego, rozpoznanie pierwszego obiektu tego typu, zdobycie cennych doświadczeń), praktycznie wobec nieistnienia w sztabie armii oddziału rozpoznawczego, limitował jednocześnie możliwość utrzymania z grupą kontaktów i korygowania przez sztab jej działaniem”. Ibid., Sprawozdanie z organizacji i przebiegu działań organów rozpoznania i sił specjalnych w operacji „Dunaj”, Warszawa 1968, 16. W kolejnej akcji użyto 48 żołnierzy, a następnie liczbę ich jeszcze zmniejszono, w zależności od stopnia trudności planowanego zadania (wahała się ona od 8 do 25 ludzi).

46 Dowódca 1 bszt pod wpływem tych niepowodzeń sugerował po zakończeniu działań, że jego żołnierzy należałoby wyposażyć w zestawy do pracy pod wysokim napięciem i miotacze ognia. AIPN, Zarząd II SG, 2602/8445, Propozycje i wnioski z działań grup 1. batalionu szturmowego, b.m., 23 IX 1968 r., 200. Problem z trwałym uciszeniem danej radiostacji 
nieznajomość języka czeskiego i - co godne uwagi - braki w przygotowaniu do „fizycznego unieszkodliwiania przeciwnika bez potrzeby uciekania się do noża, pistoletu itp. [...] w sytuacji czechosłowackiej, gdzie unikano drastycznych i konfliktowych spięć, były one dość dużą przeszkodą". ${ }^{47}$ Obsadę radiostacji stanowili na ogół członkowie lokalnej samoobrony wspierani niekiedy przez pododdziały wojska. ${ }^{48}$

Najbardziej rażące i potencjalnie wielce brzemienne w skutkach było słabe rozpoznanie i planowanie działań. O otrzymaniu konkretnego zadania dowódca danej grupy specjalnej dowiadywał się kilkanaście minut przed odlotem śmigłowca, a planowanie jego wykonania odbywało się w trakcie lotu, precyzowanie zaś - po wylądowaniu. Jak pisał dowódca grupy specjalnej nr 3, ppor. Edward Warych: „Grupa najczęściej zrywana była natychmiastowo i decyzję trzeba było wypracować podczas jazdy [do śmigłowca] [i lotu], co nieraz również było niedogodne z różnych względów (ciemno, warkot silników itp.). Powodowało to, iż zwiadowcy nieraz dobrze nie znali swojego zadania. Zadanie stawiało się podczas ataku na obiekt, co powodowało, że powstawał chaos i nieład w poszczególnych grupach. [...] Nie wiedziano np. co zrobić, ażeby unieruchomić pracę radiostacji na dłuższy okres czasu"49. Warto byłoby zacytować celną opinię ówczesnego wiceministra obrony narodowej i zastępcy Naczelnego Dowódcy Zjednoczonych Sił Zbrojnych Układu Warszawskiego, gen. Tadeusza Tuczapskiego: „Brakowało nam też sił i środków, by skutecznie wyeliminować $\mathrm{z}$ eteru wrogo do nas usposobione stacje radiowe i radiostacje. Brak było również skutecznych środków zakłócania tego typu działalności. Nie mieliśmy również rozpoznania co do ich dyslokacji w terenie". ${ }^{50}$ Pewne problemy stwarzało również ograniczone prowadzenie dokumentacji na piśmie z uwagi na to, że „nikt nie żądał takiej sprawozdawczości i takiej dokumentacji”. ${ }^{51}$

22 sierpnia „odwód specjalny” otrzymał zadanie opanowania radiostacji położonej kilometr na zachód od miejscowości Poděbrady, co wykonano za

wynikał $\mathrm{z}$ tego, że komandosom nie pozwolono dokonywać zniszczeń. Królikowski, 1 Batalion Szturmowy, 105.

47 AIPN, Zarząd II SG, 2602/8445, Sprawozdanie z organizacji i przebiegu działań organów rozpoznania i sił specjalnych w operacji „Dunaj”, Warszawa 1968, 10.

48 Jak zapisano $\mathrm{w}$ jednym $\mathrm{z}$ dokumentów analizujących przebieg działań 1 bszt przygotowanym przez jego dowódcę: „Ochronę radiostacji w zasadzie stanowili wartownicy cywilni w czasie pokoju, a w czasie działań grupy samoobrony wsparte pododdziałami wojska”. Ibid., Propozycje i wnioski wynikające z działań grup 1. batalionu szturmowego, b.m., 23 IX 1968 r., 200.

49 Ibid., Wnioski z działania grupy specjalnej nr 3, b.m., b.d., 205.

50 Kowalski, Kryptonim „Dunaj”, 35.

51 AIPN, Zarząd II SG, 2602/8445, Wnioski taktyczne i propozycje szkoleniowe w świetle działań specjalnych prowadzonych w operacji „Dunaj”, Warszawa 1968, 26. 
pośrednictwem pięciu grup specjalnych transportowanych przez śmigłowce Mi-8. Radiostację unieszkodliwiono pół godziny po wylądowaniu. W nocy z 22 na 23 sierpnia „odwód specjalny”, na rozkaz dowódcy 2 Armii, przegrupował się na lotnisko w rejonie miejscowości Hradec Králové, gdzie rozwinięto również stanowisko dowodzenia armii, a następnie wykonywał zadania mające na celu unieszkodliwienie radiostacji w miejscowości Stěžery (zadanie wykonane przez trzy grupy specjalne przy wsparciu transporterów opancerzonych), Trotina (nie odnaleziono celu) oraz Litomyšl-Pohodli ${ }^{52}$ (zadanie wykonane przez dwie grupy specjalne przewiezione śmigłowcami Mi-8). Prócz tego trzy grupy specjalne na transporterach opancerzonych opanowały czechosłowacką Komendę Garnizonu w Hradec Králové. ${ }^{53}$ Polacy brali również udział w poszukiwaniu radzieckiego specjalnego transportu kolejowego nr 2122 (przewoził urządzenia łączności dużej mocy), który został następnie odeskortowany do Pragi. ${ }^{54}$

Trzy dni później (26 sierpnia) rozpoznawano, bez efektu, domniemane miejsca postoju czechosłowackich samolotów w rejonie miejscowości Milovice i Klenice. Maszyny te miały rzekomo zostać ukryte w stodołach i pozostawać $\mathrm{w}$ gotowości do startu $\mathrm{z}$ szosy, a zadaniem Polaków w przypadku zlokalizowania odrzutowców było ich uszkodzenie. ${ }^{55} 26$ sierpnia „odwód specjalny” rozpoznał także (przy pomocy śmigłowców) magazyny amunicji i sprzętu (wykryto łącznie trzy magazyny - w dwóch zgromadzono zapasy paliw i smarów, a w jednym materiały wybuchowe). Tego też dnia ppłk Wandzel wydał rozkaz specjalny o następującej treści: „Żołnierze! Jednostce naszej przypadło w udziale, wraz z Armią Radziecką i innymi sojuszniczymi armiami, pośpieszyć na pomoc narodom Czechosłowacji, w celu udaremnienia prób wyrwania Czechosłowacji z grona krajów wspólnoty socjalistycznej. Udział żołnierzy naszej jednostki w wykonywaniu specjalnych zadań na terenie Czechosłowacji jest dla nas wielkim wyróżnieniem

\footnotetext{
52 Radiostację ochraniało ponoć ok. 200 żołnierzy czechosłowackich, którzy jednak okazali się tak zdemoralizowani, że nie stawiali żadnego oporu 17 żołnierzom 1 bszt. Zob. Kowalski, Kryptonim „Dunaj”, 70. Według czeskiego autora misja ta zakończyła się tylko krótkotrwałym sukcesem: „Ze względu na to, że żołnierze polscy widocznie nie znali się na technice, po krótkiej przerwie emisja została wznowiona. Nadawanie $\mathrm{z}$ tego miejsca trwało aż do 9 września 1968 r.”, zob. Jan Kalous, „Reakcje społeczeństwa czechosłowackiego na udział Polski w interwencji 1968 roku", w Wokół, 128.

53 AIPN, Zarząd II SG, 2602/8445, Sprawozdanie z działań 1 bszt na ćwiczeniach „Pochmurne Lato", b.m., 30 VIII 1968 r., 79.

54 Kowalski, Kryptonim „Dunaj”, 66.

55 Odnaleziono jedynie samolot umieszczony na postumencie w jednaj z wiosek jako „pomnik historii”. Odrzutowiec ten, błędnie rozpoznany z powietrza jako maszyna operacyjna, okazał się przyczyną zbędnych działań poszukiwawczych. Królikowski, 1 Batalion Szturmo$w y, 106$.
} 
i wyrazem zaufania, jakie zdobyliśmy w oczach naszych przełożonych. W dotychczasowych działaniach żołnierze naszej jednostki wykazali wiele patriotycznej postawy i odwagi godnych żołnierzy batalionu szturmowego. Za wasz trud żołnierski, za odwagę i wasze oddanie sprawie Partii i Władzy Ludowej wyrażam Wam w imieniu służby najwyższe uznanie". ${ }^{56}$

27 sierpnia opanowano i utrzymano do czasu przybycia piechoty zmechanizowanej magazyn broni położony w lesie kilka kilometrów na wschód od miejscowości Kolín. Zadanie wykonano przy pomocy trzech grup specjalnych przerzuconych śmigłowcami, które po rozpoznaniu obiektu wzmocniły dwie kolejne. ${ }^{57}$ Przebieg akcji 1 bszt ogólnie charakteryzowano następująco: „Działania szturmowe były [...] w warunkach czechosłowackich najbardziej typową formą zbrojnego oddziaływania na przeciwnika. Polegały one na zdecydowanym, otwartym działaniu grupy specjalnej bezpośrednio na obiekt, śmiałym wkraczaniu do akcji bojowej bezpośrednio ze śmigłowców. [...] W nieco innym ujęciu przeprowadzano działania szturmowe ze środków transportu kołowego. Stosowano je głównie w odniesieniu do magazynów uzbrojenia, komend garnizonów i lotnisk. Inne ujęcie powodowane było głównie potrzebą skrytego i cichego podejścia do obiektu połączonego najczęściej z jego lokalizacją i ustaleniem najdogodniejszych podejść. Sama jednak akcja przeprowadzana była w podobny jak wyżej sposób" ${ }^{58}$

Warto byłoby również zacytować fragment sprawozdania dowódcy grupy specjalnej nr 6, ppor. Włodzimierza Łady: „Najbardziej charakterystyczna akcja, to działanie na magazyn amunicji. Grupa wylądowała w rejonie koszar, gdy z lasu (magazynu amunicji) wyjeżdżała kolumna samochodów. Dwie grupy [specjalne] zatrzymały około piętnastu samochodów i około pięćdziesięciu żołnierzy, a dwie pojechały do lasu, gdzie był magazyn. Grupy rozbroiły wartę tylko na wartowni, a żołnierze grupy dublowali żołnierzy czeskich na posterunkach. Po 24 godzinach grupy zostały podmienione przez innych żołnierzy". ${ }^{59}$

Z powyższych cytatów wynika, że żołnierze 1 bszt wykonywali działania specjalne o zróżnicowanym charakterze, które $\mathrm{z}$ natury rzeczy wymagały odpowiedniego wyszkolenia i taktyki. Można jedynie domniemywać, jak poradziłyby sobie $\mathrm{z}$ ich realizacją inne jednostki armii, aczkolwiek raczej na pewno ich skuteczność byłaby mniejsza.

\footnotetext{
56 AWO, Z-874: 1 bszt, 6415/16/1, Rozkaz specjalny dowódcy 1. bszt. nr PF 1, Hradec Králové, 26 VIII 1968 r., 188.

57 AIPN, Zarząd II SG, 2602/8445, Sprawozdanie z działań 1. bszt na ćwiczeniach „Pochmurne Lato", b.m., 30 VIII 1968 r., 79.

58 Ibid., Wnioski taktyczne i propozycje szkoleniowe w świetle działań specjalnych prowadzonych w operacji „Dunaj”, Warszawa 1968, 9-10.

59 Ibid., Wnioski z działania grupy specjalnej nr 5, b.m., b.d., 207.
} 
29 sierpnia grupa specjalna $\mathrm{nr} 3$, przemieszczająca się śmigłowcami Mi-8, opanowała radiostację przekaźnikową w rejonie miejscowości Krásné (ok. $16 \mathrm{~km}$ na południowy zachód od miejscowości Chrudim), a także obsługujące je radiostacje wojskowe w liczbie 15. Dowódca 1 bszt, który brał udział w tej akcji, opisał ją następująco: „Decyzję podjąłem następującą: osłaniając się siłami dwóch grup, osobiście $\mathrm{z}$ oficerem tłumaczem i dowódcą kompanii wejść do wnętrza dla sprawdzenia treści transmitowanych programów. Następnie, pod pozorem zagrożenia ze strony sił nielegalnie działających, wprowadzić do środka jedną grupę w celu przeciwdziałania ewentualnym próbom nadawania nielegalnych programów do czasu zluzowania przez siły 11. Dywizji Pancernej. Wykonano zadanie zgodnie z decyzją z następującą zmianą wynikłą z powodu wykrycia na dziedzińcu piętnastu wojskowych radiostacji na samochodach. Dla zablokowania wyżej wymienionych radiostacji dodatkowo ukryłem w pobliskim lesie jedną grupę, która ma ewentualnie wkroczyć do akcji, gdy zajdzie potrzeba. W toku wykonywania zadania stwierdziłem, że 100 proc. obsługi radiostacji - około trzydziestu osób - to prawie wszyscy są nastawieni wrogo". ${ }^{60}$ Było to ostatnie osiągnięcie 1 bszt. Jak zapisano $\mathrm{w}$ sprawozdaniu $\mathrm{z}$ działań 2 Ośrodka Rozpoznania Radioelektronicznego: „W dniach 29 sierpnia-1 września 1968 r. powyższe [rozpoznane przez 2 Ośrodek] radiostacje nadal pracowały [...], jednakże nadawane audycje nie miały już charakteru wrogiej propagandy, lecz mówiły o stabilizacji życia w Czechosłowacji, nawoływały ludność do powrotu do normalnego trybu życia". ${ }^{61}$ Zastępca dowódcy 2 Armii ds. politycznych podsumował „polowanie na radiostacje” następująco: „Gdy przekraczano wszelkie normy rzetelnej informacji [sic!], wkraczali nasi komandosi".62

\section{W oczekiwaniu na wycofanie}

Od 29 sierpnia do 1 września żołnierzom 1 bszt nie przydzielono żadnych zadań. 2 września postanowiono ich wykorzystać do oddziaływania na ludność cywilną, wysyłając $\mathrm{w}$ celu prowadzenia rozmów z mieszkającymi w rejonie przebywania jednostki obywatelami Czechosłowacji cztery grupy liczące po

\footnotetext{
60 AIPN, Dokumenty UW, 02958/27, Meldunek dowódcy 1. bszt z działania grup specjalnych w dn. 29 VIII 1968 r., b.m., 28-29. Zob też: ibid., Sposób wykorzystania oraz działanie pododdziałów rozpoznawczych 2. Armii w ćwiczeniach „Pochmurne Lato” i „Dunaj”, b.m., 1 X 1968 r., 174. Dwie inne grupy specjalne prowadziły w tym dniu rozpoznanie namierzonych radiostacji.

${ }^{61}$ AIPN, Zarząd II SG, 2602/8445, Sprawozdanie dotyczące pracy fonicznych nielegalnych radiostacji działających w Czechosłowacji za okres 22 VIII-11 IX 1968 r., Warszawa, b.d., 54.

62 Kowalski, Kryptonim „Dunaj”, 71.
} 
dwóch oficerów i żołnierzy każda. ${ }^{63}$ Aktywność tę kontynuowano przez dwa kolejne dni, nawiązując również kontakty z miejscową milicją i przedstawicielami rad narodowych. Od 5 do 10 września 1 bszt ponownie nie otrzymywał żadnych zadań, a jego żołnierze prowadzili rutynowe szkolenie. ${ }^{64}$ Podobnie kształtowała się sytuacja w kolejnych dniach, lecz - jak z zadowoleniem pisał zastępca dowódcy 1 bszt ds. politycznych - nie miało to negatywnego wpływu na postawę żołnierzy: „Nastroje stanu osobowego kształtują się właściwie. Pozytywny wpływ na stan nastrojów wywierają listy napływające z kraju. Na tle warunków bytowych nie spotyka się narzekań. [...] W dniu wczorajszym członkowie 1. kompanii podporządkowanej 11. Dywizji Pancernej udzielili pomocy ludności czeskiej w wykopkach ziemniaków". ${ }^{65}$

Warto dodać, że wspomniana w powyższym cytacie korespondencja, napływająca do żołnierzy 1 bszt, była stymulowana w Polsce, gdzie organy propagandy przykładały dużą wagę do tego, by do Czechosłowacji trafiło jak najwięcej listów, które zawierałyby wyrazy uznania i dumy z postawy żołnierzy WP oraz zachęty do wytrwania. Jak stwierdzał twórca jednego z dokumentów poświęconych temu zagadnieniu: „Autorzy listów zawsze kojarzą sobie wkroczenie naszych wojsk do Czechosłowacji nie tylko z jej wewnętrzną kontrrewolucją, ale w ogromnej liczbie również $[\mathrm{z}]$ jej zagrożeniem ze strony RFN"66. Po wykonaniu stosownych obliczeń okazało się, że żołnierze jednostek specjalnych otrzymali na dzień 11 października $1968 \mathrm{r}$. 120 listów z wyrazami poparcia dla ich działań (do pozostałych jednostek WP nadesłano ich do tego czasu 1756), z czego 65 wysłano z ,instytucji”, 37 ze szkół, a 18 napisały osoby prywatne. ${ }^{67}$ Korespondencja ta spełniła swoje zadanie i pomogła utrzymać wśród żołnierzy wysokie morale: „Oceniając ogólnie, była to akcja propagandowa ważna, celna i przynosząca korzyści”. ${ }^{68}$

\footnotetext{
63 Polacy stwierdzili, że najlepszą formą wpływu na obywateli Czechosłowacji była bezpośrednia rozmowa. Propaganda wizualna nie była tak skuteczna. We wsiach sprawdzały się plakaty, w miastach zaś ulotki, które rozrzucano w godz. 4:00-6:00, przed udaniem się ludności cywilnej do pracy. 1 bszt posiadał ponadto „samochód propagandowy” marki „Nysa”, lecz jego wykorzystanie było ograniczone z uwagi na niewielką ilość materiałów dźwiękowych w języku czeskim. AWO, Z-874: 1 bszt, 6415/16/1, Sprawozdanie dowódcy 1. bszt z przebiegu ćwiczeń „Pochmurne Lato”, b.m., 31 VIII 1968 r., 51-52.

${ }^{64}$ AIPN, Dokumenty UW, 02950/20, Sprawozdanie z przebiegu działań 1. bszt w ćwiczeniach „Pochmurne Lato”, b.m., 11 IX 1968 r., 189.

65 Ibid., 02958/32, Meldunek sytuacyjny o nastrojach stanu osobowego 1. bszt., b.m., 12 IX 1968 r., 44.

66 Ibid., Krótka analiza ilości i treści listów otrzymanych od społeczeństwa przez oddziały 2. Armii WP, b.m., b.d., 490.

67 Ibid.

68 Ibid. Zob. też: Robert Rybak, „Morale jako podstawowy czynnik przygotowania operacji wojskowych. Na przykładzie inwazji wojsk Układu Warszawskiego na Czechosłowację 1968
} 
Należałoby jeszcze wspomnieć informacje podane przez Jarosława Rybaka, iż żołnierze 1 bszt w końcowym okresie swego pobytu w Czechosłowacji brali udział w sianokosach i wykopkach, a także w gaszeniu płonącej stodoły. Zostali również wykorzystani do ochrony pogrzebu dwóch obywateli Czechosłowacji, zastrzelonych w nocy z 8 na 9 września w miejscowości Jičín przez pijanego polskiego żołnierza. ${ }^{69}$

20 października 1968 r. dowódca 2 Armii, gen dyw. Florian Siwicki, wydał rozkaz specjalny informujący o rozpoczęciu wycofywania się jednostek WP do kraju: „Na rozkaz Partii i Rządu, we współdziałaniu z Armią Radziecką, Narodową Armią Ludową NRD, Węgierską i Bułgarską Armią Ludową, nie bacząc na trudy i wysiłek, świadomi swego działania, przyszliście do bratniego nam kraju, by przywrócić porządek i socjalistyczny ład. Po tym akcie, który historia oceni jako działanie zapobiegające, powierzono nam pełnić odpowiedzialną i trudną wartę na straży socjalizmu przeciw zakusom imperializmu. Z zadań tych wywiązaliście się wzorowo. [...] Pamiętać musimy wszyscy - każdy na swoim żołnierskim posterunku - że wróg czyha, że nawet w godzinach radości i ciepła domowego ciąży na nas obowiązek obrony Ojczyzny, obrony socjalistycznych zdobyczy naszego narodu. [...] Jestem pewien, że wzorowym wykonaniem trzeciego etapu działań $\mathrm{z}$ radością $\mathrm{w}$ sercu powitamy V Zjazd Partii, dając tym samym dowód naszego żołnierskiego przywiązanie do Jej idei”. ${ }^{70}$ Tak "pokrzepieni na duchu” przez gen. Siwickiego żołnierze dzień później rozpoczęli wycofywanie się z Czechosłowacji, zakończone 11 listopada 1968 r. 1 bszt przegrupował się transportem kołowym do rejonu leżącego na północny wschód od Lubawki, skąd 22 października został załadowany do transportu kolejowego do Kamienia Pomorskiego. Ostatni, krótki odcinek do garnizonu w Dziwnowie pokonano transportem kołowym. ${ }^{71}$

W toku operacji „Dunaj” żołnierze polskich jednostek specjalnych nie zapisali na swym koncie ofiar po stronie czechosłowackiej: „działalność sił specjalnych pomyślana była $\mathrm{w}$ ten sposób, by unikać starć zbrojnych w konfliktowych sytuacjach, doprowadzić do wystąpienia faktów nieodwracalnych, paraliżując przez to swobodę działania wrogich nam sił i to zarówno tych

- operacja «Dunaj»," w Wojny i konflikty zbrojne po 1945 roku. Zbiór studiów, t. 2, red. Mirosław Giętkowski i Łukasz Nadolski (Bydgoszcz: Muzeum Wojsk Lądowych, 2016), 203-227.

69 Rybak, „Czeska wojna,” 59. Zob. AWO, Z-874: 1 bszt, 6415/16/1, Rozkaz specjalny dowódcy 2. Armii WP nr PF 418, b.m., 12 IX 1968 r., 314; Gaj, „Wojsko Polskie,” 95-96.

70 AIPN, Dokumenty UW, 02958/32, Rozkaz specjalny nr 840 dowódcy 2. Armii WP czasowo stacjonującej w Czechosłowackiej Republice Socjalistycznej, Hradec Králové, 20 X 1968 r., 510, 512.

71 Pajórek, Polska a „Praska wiosna”, 216. 
otwarcie działających, jak i działających z ukrycia i w zamaskowaniu" ${ }^{72}$ Jedyny wypadek z użyciem broni miał miejsce 30 września 1968 r., gdy szer. Henryk Chojnacki z 1 bszt wskutek nieostrożnego obchodzenia się z bronią zastrzelił stojącego na posterunku szer. Tadeusza Grupę. ${ }^{73}$ Powrót jednostek WP do kraju uznano za doskonałą okazję do kolejnej, po akcji pisania listów, zmasowanej operacji propagandowej (m.in. organizowanie wieców, na których powracające do kraju oddziały były witane przez ludność z miejscowości znajdujących się na trasie ich przemarszu do garnizonu) mającej poprawić nastroje opinii publicznej i wojska. ${ }^{74}$

\section{Podsumowanie}

Chociaż w ocenie dowódcy 1 bszt jednostka podczas interwencji w Czechosłowacji prezentowała się bardzo dobrze i wykazała się pełną gotowością do działań bojowych, to trudno nie zauważyć wielu problemów, które wynikały zarówno z niedostatecznej koordynacji działań i ograniczeń jednostek wspieranych przez 1 bszt, jak i z niedociągnięć, jakie ujawniły się w toku działań pododdziałów samego batalionu. Źródeł sukcesów grup specjalnych w takiej sytuacji szukać trzeba było przede wszystkim w braku zbrojnego oporu ze strony czechosłowackiej podczas wykonywania poszczególnych zadań. Jak pisano w jednej z analiz: „żaden ze sposobów działania sił specjalnych nie zmuszał do zakładania bazy w oderwaniu od głównych zgrupowań wojsk, nie zmuszał do samodzielności życia i bytowania tych ludzi”. ${ }^{75}$ Zwracano uwagę na długie przestoje w działaniach 24, 25 i 26 sierpnia, kiedy to aktywność jednostek specjalnych była niewielka. Część zadań odwoływano, prawie nie wykonywano ich w nocy, niejednokrotnie grupy specjalne zmuszone były do oczekiwania na śmigłowce skierowane do innych zadań (maszynom tym nie przydzielono eskorty śmigłowców szturmowych) lub

\footnotetext{
72 AIPN, Zarząd II SG, 2602/8445, Wnioski taktyczne i propozycje szkoleniowe w świetle działań specjalnych prowadzonych w operacji „Dunaj”, Warszawa 1968, 5.

73 Gaj, „Wojsko Polskie,” 96. Zob. też: AWO, Z-874: 1 bszt, 6415/16/1, Pismo szefa sztabu 2. Armii WP w sprawie zwalczania przejawów rozluźnienia dyscypliny wojskowej, b.m., $4 \mathrm{X}$ 1968 r., 524.

74 Jak wyglądało to w praktyce, przedstawiono np. w Zbigniew Łakomski, „Wojsko wraca,” Trybuna Ludu, październik 28, 1968. W prasie przedstawiano również idealizowane obrazy działań w Czechosłowacji. Jednym z przykładów mógł być artykuł opublikowany w Żołnie$r z u$ Wolności opisujący rozpoznanie z powietrza „nielegalnych radiostacji”. Bogdan Bartoszewski, „Nasi żołnierze w CSRS,” Żołnierz Wolności, sierpień 31, 1968. Drugim zaś tekst poświęcony żołnierzom 1 bszt: Jan Budziński, „Ci z desantu,” Żołnierz Wolności, wrzesień 20, 1968.

75 AIPN, Zarząd II SG, 2602/8445, Wnioski taktyczne i propozycje szkoleniowe w świetle działań specjalnych prowadzonych w operacji „Dunaj”, Warszawa 1968, 8.
} 
poprawę pogody. Ponadto Polakom w kilku przypadkach sprzyjało szczęście. Trudno sobie jednak wyobrazić jak, przy braku rozpoznania, słabym planowaniu oraz istniejących ograniczeniach użytkowanego sprzętu i wyszkolenia, zakończyłyby się działania 1 bszt przeciwko stawiającej opór armii czechosłowackiej, o regularnych jednostkach NATO nie wspominając. ${ }^{76}$

Zawiodło także dowództwo 2 Armii, które przesadnie obawiając się o swoje bezpieczeństwo na terenie Czechosłowacji, wydzielało jednostki specjalne (m.in. 62 Armijną Kompanię Specjalną) do ochrony sztabu, zadań konwojowych, a nawet zbierania „wrogich” ulotek. Jak wspomniał jeden $\mathrm{z}$ weteranów 62 Kompanii, Ryszard Baranowski: „Byłem w obstawie gen. broni ${ }^{77}$ Włodzimierza Sawczuka, zastępcy dowódcy ds. politycznych Śląskiego Okręgu Wojskowego. Wszędzie za nim chodziliśmy, ale nie pamiętam jakichś niebezpiecznych sytuacji"." Takie postępowanie, polegające na dawaniu żołnierzom elitarnych jednostek zadań, które mogły być z powodzeniem wykonywane przez inne oddziały, oceniono bardzo krytycznie, wskazując na spowodowane przez nie ujemne zjawiska, które najsilniej wystąpiły w 62 Kompanii: „niezgodne z przeznaczeniem wykorzystanie armijnej kompanii specjalnej oraz odebranie jej czerwonych beretów i niezapewnienie żołnierzom umundurowania skoczków spadochronowych znacznie obniżyło poczucie własnej wartości wśród oficerów i żołnierzy tej kompanii, a w dodatku bardzo ujemnie wpłynęło na stan moralny pododdziału. Żołnierze kompanii odczuwali powyższe, jako wyrządzoną im krzywdę i brak zaufania".79

76 Jak wspomniał weteran 62 Armijnej Kompanii Specjalnej wkroczenie do Czechosłowacji w nocy z 22 na 23 VIII 1968 r.: „Jechaliśmy wąwozami. Przypominało mi się, jak w «Potopie» górale atakują Szwedów. Czesi nawet nie musieli do nas strzelać, mogli nas wtedy zarzucić kamieniami. Gdyby tylko chcieli, to w tych wąwozach by nam dupę zerżnęli [sic!]. Teren był bardzo dogodny do obrony”. Cyt. za: Rybak, Commando: nieznana historia, 32. Podpułkownik Wandzel na bazie doświadczeń uzyskanych w toku operacji „Dunaj” postulował przydzielenie w przyszłości jego żołnierzom moździerzy lub dział bezodrzutowych, „ponieważ w przeciwnym razie zostaną poniesione duże straty w sile żywej”. Oficer sugerował ponadto m.in. zwiększenie zespołu operacyjnego, by móc sprawnie kierować jednocześnie działaniami wielu grup specjalnych, a także zwracał uwagę na problemy z utrzymaniem łączności między poszczególnymi grupami (kłopoty z radiostacjami R-352). AIPN, Dokumenty UW, 02958/27, Ocena i wnioski z zakresu organizacji i wyposażenia pododdziałów i sztabu 1. bszt., b.m., 1 X 1968 r., 185.

77 W 1968 r. Włodzimierz Sawczuk miał stopień generała brygady. Generałem broni został dopiero we wrześniu 1975 r. (wcześniej, we wrześniu 1972 r., otrzymał awans do stopnia generała dywizji).

78 Cyt. za: Rybak, Commando: nieznana historia, 35.

79 AIPN, Zarząd II SG, 2602/8445, Sprawozdanie z organizacji i przebiegu działań organów rozpoznania i sił specjalnych w operacji „Dunaj”, Warszawa, 1968, 19-20. Zob. też: AIPN, Dokumenty UW, 02958/27, Protokół z kontroli 62. kompanii rozpoznania specjalnego przeprowadzonej 2 IX 1968 r. przez komisję sztabu 2. Armii, b.m., 4 IX 1968 r., 
Niemniej, biorąc pod uwagę fakt, że żołnierze jednostek specjalnych ochraniali na terenie Czechosłowacji wielu wpływowych wyższych oficerów WP, wykorzystanie ich $\mathrm{w}$ tym celu ostatecznie udało się zgrabnie uzasadnić: „Wydaje się, że chęć korzystania z żołnierzy tej specjalności nosiła w warunkach czechosłowackich nie tyle potrzebę bojowego ich wykorzystania na tym odcinku, ile potrzebę psychicznego uodpornienia określonych organów dowodzenia. Fakt, że otrzymuje się do obrony doborowego żołnierza - za takich zresztą uważa się żołnierzy sił specjalnych - miał w warunkach operacji «Dunaj» zasadnicze znaczenie i trudno negować możliwość stosowania takiego rozwiązania w przyszłości" ${ }^{80}$

Niezadowolenie wśród oficerów 1 bszt wywołało też wydzielenie dwóch kompanii szturmowych i przydzielenie ich dywizjom pancernym, co $\mathrm{w}$ znacznym stopniu wiązało się z przejęciem zadań związanych m.in. z regulacją ruchu i rozpoznaniem. Kapitan Kazimierz Bielecki, jeden z oficerów, który w sierpniu pełnił krótko obowiązki szefa sztabu batalionu, a następnie brał udział w działaniach grup specjalnych, odniósł się do tego następująco: „Niesłusznie angażowano grupy specjalne w sile dwóch kompanii, które musiały potężne związki pancerne prowadzić do granicy, a później jeszcze do celu po wyznaczonych drogach marszu. Po co więc te związki miały etatowe oddziały rozpoznawcze, one powinny wykonywać takie zadania. Wykorzystano nas niezgodnie z naszym przeznaczeniem. Toć śmiechu warte, żeby błądzić po trasie; to wstyd dla sztabów tych dywizji, by nasi oficerowie byli wzywani na czoło kolumn tych kolosów i prowadzili je do rejonów ześrodkowania [...], bo ich rozpoznanie nie było w stanie dotrzeć do celu"."

Co godne odnotowania, w toku operacji „Dunaj” w 1 bszt nie stwierdzono żadnych problemów w zakresie politycznej postawy żołnierzy. Jak meldował 13 września 1968 r. dowódca batalionu: „W obecnej chwili stan moralno-polityczny w całym stanie osobowym batalionu jest dobry,

63-65. Należałoby wszakże zauważyć, że żołnierze 62 Armijnej Kompanii Specjalnej, oprócz ochrony sztabu 2 Armii, brali również udział w rozpoznaniu obiektów wojskowych (koszary, magazyny), radiostacji wykrytych przez 11 Batalion Rozpoznania Radioelektronicznego (oficerowie kompanii na pokładach śmigłowców) oraz poszukiwaniach oficerów radzieckich w rejonie miejscowości Krasíkov i Zábřeh. AIPN, Dokumenty UW, 02958/27, Sprawozdanie szefa sztabu 2 Armii płk. Tadeusza Bełczewskiego z działalności rozpoznawczej organów 2. Armii w okresie 28 VII-3 IX 1968 r., b.m., 48.

80 AIPN, Zarząd II SG, 2602/8445, Wnioski taktyczne i propozycje szkoleniowe w świetle działań specjalnych prowadzonych w operacji „Dunaj”, Warszawa, 1968, 10-11. Jak wspomniał później jeden z weteranów 62 Kompanii, por. Andrzej Żdan: „Wśród miejscowych czerwone berety budziły powszechny strach. Dlatego każdy ważniejszy polski dowódca chciał mieć ochronę złożoną z naszych ludzi. Dochodziło do tego, że wyjeżdżający na patrole żołnierze $\mathrm{z}$ jednostek regularnych pożyczali od nas berety, bo wtedy miejscowi zachowywali się mniej agresywnie”. Cyt. za: Rybak, „Czeska wojna, 59.

81 Kowalski, Kryptonim „Dunaj”, 133. 
a nastroje są ukierunkowane na najlepsze wykonania zadania postawionego przez Dowództwo Armii i jednostki. Do obecnej chwili nie było na terenie Czechosłowacji żadnych wykroczeń dyscyplinarnych i nie ma tzw. trudnych żołnierzy. Kadra i żołnierze w pełni rozumieją potrzebę pobytu w Czechosłowacji, co uwidacznia się w dyskusjach, rozmowach oraz na zebraniach partyjnych" ${ }^{82}$ Przynajmniej w tym aspekcie program szkoleniowy sprawdził się idealnie.

Sztab Generalny WP był świadomy powyższych faktów, niemniej działania w toku operacji „Dunaj” wykazały także bardzo duży potencjał zastosowania jednostek specjalnych w przyszłości: „Uznano, że pododdziały specjalne (zwłaszcza 1 bszt) właściwie wywiązały się ze swej roli, wzorowo wykonując postawione im zadania. Wykazały się przy tym odwagą, brawurą i wielką bojowością. Aczkolwiek część zadań nie mieściła się w poglądach na dotychczasowe zasady użycia tych sił, w istniejących okolicznościach okazały się one słuszne i wręcz konieczne do realizacji przez siły specjalne". ${ }^{83} \mathrm{Z}$ interwencji w Czechosłowacji wyciągnięto wnioski wskazujące na to, że jednostki specjalne umożliwiały utrzymanie wysokiego tempa działań wojsk, z możliwością szybkich interwencji, a ich głównym środkiem przerzutu winny być śmigłowce (ewentualnie samoloty, samochody i transportery opancerzone). Stwierdzono, że każda armia i dywizja powinna mieć własną grupę dowodzenia jednostkami specjalnymi podlegającą oddziałowi rozpoznawczemu sztabu armii, której członkowie nie powinni się bezpośrednio angażować w działania bojowe. Jednostki specjalne powinny nadto w większym niż dotąd zakresie dysponować organicznym transportem powietrznym.

W kolejnych latach dążono do rozbudowy polskich jednostek specjalnych, poprawy poziomu ich wyszkolenia oraz przekazania im sprzętu, który umożliwiałby skuteczniejsze działanie. Rezultaty okazały się wszakże niezadowalające. Szczególnie dotkliwe były kwestie sprzętowe. Przykładowo podczas szkolenia na początku $1970 \mathrm{r}$. wystąpiły poważne problemy z łącznością. Spośród piętnastu „wyrzuconych w teren” radiostacji bez zarzutu pracowały tylko dwie. ${ }^{84}$ Swoją rolę odegrały w tym niewątpliwie ograniczenia w budżecie Ministerstwa Obrony Narodowej wynikające z kryzysu ekonomicznego w kraju, który swoje apogeum osiągnął na początku lat osiemdziesiątych. W jednym z dokumentów z połowy $1981 \mathrm{r}$. opisano to

82 AIPN, Dokumenty UW, 02958/27, Warunki bytowania 1. bszt i potrzeby związane z pobytem w Czechosłowackiej Republice Socjalistycznej, b.m., 13 IX 1968 r., 140.

83 AIPN, Zarząd II SG, 2602/8445, Sprawozdanie z organizacji i przebiegu działań organów rozpoznania i sił specjalnych w operacji „Dunaj”, Warszawa 1968, 18.

84 Ibid., 2602/10500, Notatka służbowa z obserwacji szkolenia 1. bszt prowadzonego przez Oddział Rozpoznawczy Inspektoratu Szkolenia Ministerstwa Obrony Narodowej na terenie miejscowości Dziwnów, b.m., 27 I 1970 r., 61. Radiostacje nie zostały odpowiednio wyskalowane. 
następująco: „Jednostki działań specjalnych posiadają trudności w realizacji programu szkolenia spadochronowego $\mathrm{z}$ uwagi na niewielkie ilości spadochronów treningowych [...]. Pomimo posiadania niezbędnych ilości limitów (godzin) wykorzystania samolotów i śmigłowców, są duże trudności z ich zapotrzebowaniem nawet na programowe szkolenie. [...] Przedstawiane w sprawozdaniach ilości radiostacji R-350, R-353 i R-354 nie odzwierciedlają faktycznego stanu w jednostkach. Część radiostacji (w 1 bszt - 6 szt.) od kilku lat znajduje się w warsztatach okręgowych łączności i z uwagi na ich unikalność (niepowtarzalność) konstrukcyjną nie może być w Polsce naprawiona, podczas gdy w sprawozdaniach wykazuje się, że radiostacje te są na wyposażeniu pododdziałów. [...] Zwrócono uwagę na minimalny dopływ jakiegokolwiek nowego wyposażenia do jednostek w ostatnich siedmiu latach oraz że na rynku cywilnym pojawił się w międzyczasie sprzęt turystyczny funkcjonalny i przydatny $\mathrm{w}$ działaniach specjalnych (np. toporek wieloczynnościowy). Natomiast [...] nie czyni się wszystkiego, aby tego typu sprzęt znalazł się w jednostkach działań specjalnych". ${ }^{85}$

Upływający czas przyniósł jedynie pogorszenie sytuacji. W dokumencie z maja 1984 r. można było przeczytać m.in.: „Aktualnie posiadane przez nas siły działań specjalnych, zarówno w wojskach lądowych, jak i marynarce wojennej, są zbyt małe $\mathrm{w}$ stosunku do potrzeb wynikających $\mathrm{z}$ zadań rozpoznawczych przewidywanych dla działań specjalnych kształtowanych ilością i charakterem obiektów nieprzyjaciela, jak i obszarami zainteresowania poszczególnych związków operacyjnych i taktycznych, a także charakteru terenu. Brak w ogóle grup specjalnych kadrowych wyspecjalizowanych w prowadzeniu działań w aglomeracjach miejskich i obszarach zurbanizowanych oraz grup rajdowo-szturmowych do wykonywania szczególnie ważnych zadań o charakterze dywersyjnym. Aktualnie istniejący pododdział działań specjalnych Marynarki Wojennej (trzy grupy specjalne płetwonurków) zabezpiecza jej potrzeby zaledwie w ok. 15 proc.". ${ }^{86}$

Rozwój polskich jednostek specjalnych po 1968 r. jest już jednak zagadnieniem wartym osobnej publikacji. W tym miejscu można jeszcze tylko zauważyć, że liczne niedociągnięcia zaobserwowane w 1 bszt podczas operacji „Dunaj”, w dużym stopniu były rzeczą naturalną w przypadku jednostki tak młodej i mającej eksperymentalny charakter. Przełożeni docenili także ppłk. Wandzela, o którym w opinii służbowej sporządzonej w $1969 \mathrm{r}$. zapisano m.in.: „Jest oficerem energicznym i pilnym [...]. W działaniu wykazuje odwagę, o czym świadczą pozytywne opinie i wyróżnienia w okresie

85 Ibid., 2602/15914, Notatka służbowa ppłk. Andrzeja Krawczyka w sprawie organizacji i przeprowadzenia Centralnego Kursu Kadry Działań Specjalnych, b.m., 4 VI 1981 r., 111-116.

86 Ibid., 2602/18754, Projekt perspektywicznego rozwoju jednostek działań specjalnych, b.m., 23 V 1984 r., 38-39. 
wykonywania zadań bojowych w operacji «Dunaj», podczas których należycie wykonywał rozkazy przełożonych dając podwładnym godny przykład śmiałości i bojowości”. ${ }^{87}$

Naturalnie z moralnego punktu widzenia operację „Dunaj” należałoby ocenić w sposób jednoznacznie negatywny. Warto byłoby zauważyć, że wiele spośród osób obsługujących "nielegalne radiostacje” zostało w toku późniejszego procesu „normalizacji” odwołanych ze stanowisk, ukaranych grzywnami, zwolnionych z pracy, a represje dotknęły także członków ich rodzin. ${ }^{8}$

87 CAW-WBH, TAP, 1562/74/452, Opinia służbowa dotycząca ppłk. Tadeusza Wandzela za okres od 1 VIII 1967 r. do 30 XI 1969 r., b.m., b.d., 8.

88 Kalous, „Reakcje społeczeństwa czechosłowackiego,” 128. 


\section{Aneks nr 1}

Wykaz stanu osobowego grup szturmowych $n r$ 1-7 wyodrębnionych $z$ „odwodu specjalnego"

\section{Grupa nr 1:}

por. Kazimierz Anaszko - dowódca

st. szer. Andrzej Suchojad - zastępca dowódcy

st. szer. Jerzy Duch - radiotelegrafista

st. szer. Zbigniew Gackowski

st. szer. Wiesław Adamczak

szer. Zbigniew Dasiewicz

szer. Bernard Peterson

szer. Piotr Kuźmiński

\section{Grupa nr 2:}

ppor. Tadeusz Płaczkiewicz - dowódca

kpr. Jerzy Pawlak - zastępca dowódcy

szer. Andrzej Osieja - radiotelegrafista

st. szer. Leszek Kułak

st. szer. Edward Chwiałkowski

szer. Jan Boruta

szer. Józef Jończak

szer. Jan Skiba

Grupa nr 3:

ppor. Edward Warych - dowódca

kpr. Wacław Jezierski - zastępca dowódcy

szer. Stodulny - radiotelegrafista

szer. Blok

szer. Mąkowski

szer. Kulikowski

szer. Kopernik

szer. Gryszkiewicz

\section{Grupa nr 4:}

por. Zdzisław Grabowski - dowódca grupy

kpr. Wojciech Szkop - zastępca dowódcy

st. szer. Janusz Płoszaj - radiotelegrafista

szer. Stanisław Sadłowski

szer. Miszczak Daniel

szer. Zdzisław Wojtczak 
szer. Zdzisław Kazimierczak

st. szer. Jerzy Dziąg

Grupa nr 5:

ppor. Jan Lipecki - dowódca grupy

st. szer. Jan Sieradzki - zastępca dowódcy

st. szer. Eugeniusz Torzewski - radiotelegrafista

szer. Andrzejczak

szer. Krzysztof Łysakowski

szer. Eugeniusz Tarłowski

szer. Andrzej Czepek

st. szer. Jan Antczak

Grupa nr 6:

ppor. Włodzimierz Łada - dowódca grupy

st. szer. Kalecki Grzegorz - zastępca dowódcy

szer. Antoni Puzik - radiotelegrafista

szer. Jankowski

szer. Feliks Pachla

st. szer. Tadeusz Erdman

szer. Drzewiecki

Grupa nr 7:

sierż. Tadeusz Susin - dowódca grupy

st. szer. Andrzej Pawłowski - zastępca dowódcy

st. szer. Zygmunt Kokoszka - radiotelegrafista

szer. Toszek

szer. Stefan Walas

szer. Mirosław Grzywacz

szer. Otrębski

szer. Leszek Cięszki

Źródło: Opracowanie własne na podstawie: Archiwum Wojskowe w Oleśnicy, Zespół 874: 1 Batalion Szturmowy, 6415/16/1, Wykaz stanu osobowego grup szturmowych zajmujących poszczególne obiekty w dniach 21-23, 26 VIII 1968 r., b.m., b.d., 41-48. 


\section{Aneks nr 2}

Wykaz oficerów i podoficerów 1 bszt odznaczonych, awansowanych lub nagrodzonych na terenie Czechosłowacji

1. ppłk Tadeusz Wandzel - Krzyż Kawalerski Orderu Odrodzenia Polski, aktówka

2. ppłk Witold Bartosiewicz - Złoty Krzyż Zasługi, Srebrny Medal „Za zasługi dla obronności kraju”, radio, maszynka do golenia

3. mjr Tadeusz Margul - awans do stopnia majora, radio

4. mjr Władysław Małyszko - Srebrny Krzyż Zasługi

5. kpt. Kazimierz Bielecki - Złoty Krzyż Zasługi, zegarek

6. kpt. Witold Jarmakowski - zegarek

7. kpt. Jan Gazarkiewicz - aktówka

8. kpt. Władysław Tkaczyk - aparat fotograficzny

9. kpt. Zbigniew Paczkowski - sweter

10.kpt. Ryszard Romańczuk - awans do stopnia kapitana, Brązowy Medal "Za zasługi dla obronności kraju”

11. por. Marian Owczarczuk - Srebrny Medal "Za zasługi dla obronności kraju”

12. por. Jan Badoń - Srebrny Medal „Za zasługi dla obronności kraju”, maszynka do golenia

13. por. Władysław Pyc - awans do stopnia porucznika

14. por. Edmund Garbaliński - sweter

15. por. Eugeniusz Browarski - Srebrny Krzyż Zasługi, Srebrny Medal „Za zasługi dla obronności kraju”, zegarek

16. por. Stanisław Lewandowski - awans do stopnia porucznika, Brązowy Medal „Za zasługi dla obronności kraju”

17. por. Stanisław Połoncarz - Brązowy Medal „Za zasługi dla obronności kraju"

18. por. Jan Łabuszewski - awans do stopnia porucznika

19. por. Bronisław Szatan - awans do stopnia porucznika

20. por. Jerzy Wróbel - awans do stopnia porucznika

21.por. Kazimierz Anaszko - awans do stopnia porucznika

22.por. Zdzisław Grabowski - Brązowy Medal „Za zasługi dla obronności kraju"

23. por. Marek Dudziński - rękawiczki

24. ppor. Edmund Nowak - maszynka do golenia

25. ppor. Edward Warych - neseser

26. por. Zbigniew Żukowski - Brązowy Medal „Za zasługi dla obronności kraju"

27.ppor. Jan Lipecki - Brązowy Medal „Za zasługi dla obronności kraju” 28. ppor. Wojciech Tkaczyk - Brązowy Medal „Za zasługi dla obronności kraju” 
29. chor. Bolesław Prus - Srebrny Krzyż Zasługi, rękawiczki

30.st. sierż. Włodzimierz Wałęsa - Brązowy Krzyż Zasługi

31.st. sierż. Władysław Sularz - Brązowy Krzyż Zasługi

32.st. sierż. Zenon Rajczyk - Brązowy Medal „Za zasługi dla obronności kraju", zegarek

33.st. sierż. Zbigniew Wójcik - Brązowy Krzyż Zasługi

34. st. sierż. Wojciech Słaby - Brązowy Krzyż Zasługi, Brązowy Medal „Za zasługi dla obronności kraju"

35. st. sierż. Józef Rycaj - awans do stopnia starszego sierżanta

36.st. sierż. Wincenty Falkowski - Brązowy Krzyż Zasługi

37.st. sierż. Jan Mielcarek - awans do stopnia starszego sierżanta

38. st. sierż. Franciszek Serafin - awans do stopnia starszego sierżanta

39. sierż. Tadeusz Rusin - Brązowy Krzyż Zasługi

40. sierż. Benedykt Sokulski - awans do stopnia starszego sierżanta, rękawiczki

41.sierż. Jan Markowicz - awans do stopnia sierżanta, sweter

42. sierż. Tadeusz Nowak - awans do stopnia sierżanta, Brązowy Medal „Za zasługi dla obronności kraju"

43. sierż. Wincenty Szymczak - awans do stopnia sierżanta

44. sierż. Władysław Sławiński - awans do stopnia sierżanta

45. sierż. Alfred Aftyka - awans do stopnia sierżanta

46. sierż. Andrzej Romański - awans do stopnia sierżanta, Brązowy Medal "Za zasługi dla obronności kraju”

47. sierż. Janusz Tomczak - awans do stopnia sierżanta

48. sierż. Wojciech Kłodaś - awans do stopnia sierżanta

49.plut. Jan Długosz - Brązowy Krzyż Zasługi

50.plut. Kazimierz Tomczyk - Brązowy Krzyż Zasługi

Źródło: Opracowanie własne na podstawie: Archiwum Instytutu Pamięci Narodowej, Zarząd II Sztabu Generalnego Wojska Polskiego, 2602/8455, Wykaz oficerów i podoficerów [1 bszt] odznaczonych i awansowanych na terenie Czechosłowacji, b.m., b.d., 209. 


\section{Aneks nr 3}

Wyciag z rozkazu personalnego dowódcy 2 Armii WP $z 8$ października 1968 r. dotyczacy odznaczeń przyznanych żotnierzom 1 bszt

Uchwałą Rady Państwa z 7 października 1968 r. odznaczeni zostali

Złotym Krzyżem Zasługi:

mjr Władysław Małyszko

Srebrnym Krzyżem Zasługi:

kpt. Władysław Tkaczyk

kpt. Włodzimierz Jarmakowski

kpt. Edmund Garbaliński

Brązowym Krzyżem Zasługi:

st. sierż. Franciszek Pozorski

sierż. Alfred Aftyka

sierż. Janusz Tomczak

plut. Jerzy Dobrogoszcz

Uchwałą Rady Państwa nr 0/416 z 7 września 1968 r. odznaczony został Krzyżem Kawalerskim Orderu Odrodzenia Polski:

ppłk Tadeusz Wandzel

na wniosek dowódcy 2 Armii Minister Obrony Narodowej nadał

Srebrny Medal „Za zasługi dla obronności kraju”:

ppłk Witold Bartosiewicz

kpt. Kazimierz Felcyn

kpt. Jan Gazarkiewicz

kpt. Zbigniew Paczkowski

por. Eugeniusz Browarski

por. Marian Owczarczuk

por. Jan Badoń

Brązowym Medalem „Za zasługi dla obronności kraju”:

kpt. Jerzy Mech

por. Edmund Garbaliński

por. Witold Kargulewicz

ppor. Edward Warych

sierż. Bernard Sokulski

Źródło: Archiwum Wojskowe w Oleśnicy, Zespół 874: 1 Batalion Szturmowy, 6415/16/1, Wyciąg z rozkazu personalnego dowódcy 2. Armii WP, b.m., 8 X 1968 r., 551. 


\section{Bibliografia}

Archiwalia

Archiwum Akt Nowych

Komitet Centralny PZPR, Wydział Zagraniczny

Archiwum Instytutu Pamięci Narodowej w Warszawie

Biblioteka byłych wojskowych organów bezpieczeństwa państwa polskiego

(Wojskowej Służby Wewnętrznej oraz Zarządu II Sztabu Generalnego WP)

Szefostwo Wojskowej Służby Wewnętrznej w Warszawie

Zarząd II Sztabu Generalnego Wojska Polskiego

Zbiór dokumentów dotyczących Układu Warszawskiego

Archiwum Wojskowe w Oleśnicy

Zespół 874: 1 Batalion Szturmowy

Centralne Archiwum Wojskowe Wojskowego Biura Historycznego

Akta personalne

\section{Literatura}

Bartoszewski, Bogdan. „Nasi żołnierze w CSRS.” Żołnierz Wolności, sierpień 31, 1968. Benken, Przemysław. „Wojna wietnamska w latach 1966-1967 w zeszytach Sztabu

Generalnego Wojska Polskiego." Studia $z$ dziejów polskiej historiografii wojskowej 13, (2012): 109-122.

Budziński, Jan. „Ci z desantu.” Żołnierz Wolności, wrzesień 20, 1968.

Bułhak, Władysław. „Kierunki badań nad udziałem Wojska Polskiego w operacji «Dunaj»" W Aparat bezpieczeństwa, propaganda a praska wiosna - zbiór materiałów z konferencji międzynarodowej. Red. Maria M. Szwykowska-Rey, 175-194. Praga: Ústav pro Studium Totalitních Režimů, 2009.

Gaj, Krzysztof. „Wojsko Polskie w operacji «Dunaj».” W Wojny i konflikty zbrojne po 1945 roku. Zbiór studiów. T. 1. Red. Mirosław Giętkowski i Łukasz Nadolski, 6797. Bydgoszcz: Muzeum Wojsk Lądowych, 2015.

Goliszewski, Czesław. „Wśród ofiarnych i odważnych ludzi.” Żołnierz Wolności, sierpień 30, 1968.

Goliszewski, Czesław i Henryk Kacała. „Wysłannicy «Żołnierza Wolności» donoszą z Czechosłowacji." Kurier Szczeciński, sierpień 23-24, 1968.

Goliszewski, Czesław i Henryk Kacała. „Wysłannicy «Żołnierza Wolności» donoszą z Czechosłowacji: Na kursie Góry Stołowe.” Kurier Szczeciński, sierpień 25, 1968.

Kalous, Jan. „Reakcje społeczeństwa czechosłowackiego na udział Polski w interwencji 1968 roku”. W Wokół Praskiej Wiosny. Polska i Czechosłowacja w 1968 roku. Red. Łukasz Kamiński, 117-137. Warszawa: Wyd. Instytutu Pamięci Narodowej, 2004.

Kamiński, Łukasz, red. Wokół Praskiej Wiosny. Polska i Czechosłowacja w 1968 roku. Warszawa: Wyd. Instytutu Pamięci Narodowej, 2004.

Kowalski, Lech. Kryptonim „Dunaj”: udział wojsk polskich w interwencji zbrojnej w Czechosłowacji w 1968 roku. Warszawa: Książka i Wiedza, 1992.

Królikowski, Hubert. 1. Batalion Szturmowy. Warszawa: Fundacja „Polonia Militaris”, 2007.

Łakomski, Zbigniew. „Wojsko wraca.” Trybuna Ludu, październik 28, 1968. 
Majchrzak, Grzegorz. „Operacja «Podhale»” W Wokół Praskiej Wiosny. Polska i Czechosłowacja w 1968 roku. Red. Łukasz Kamiński, 107-116. Warszawa: Wyd. Instytutu Pamięci Narodowej, 2004.

Maroń, Jerzy. „Konflikt w Wietnamie (1945-1975) w polskim piśmiennictwie historycznym. Kilka refleksji." W Biblioteka strategiczna. T. 1. Red. Valentin Filip i Mirosław Nagielski. 123-132. Warszawa: Wyd. DiG, Bellerive-sur-Allier: Edition La Rama, 2017.

Neja, Jarosław. „Przed żołnierzami wkroczyli agenci.” Biuletyn Instytutu Pamięci Narodowej, nr 8/9 (2003): 65-69.

Pajórek, Leszek. Polska a „Praska wiosna”. Udział wojska polskiego w interwencji zbrojnej w Czechosłowacji w 1968 roku. Warszawa: Egros, 1998.

Piotrowski, Paweł. „Udział Wojska Polskiego w interwencji w Czechosłowacji.” W Wokół Praskiej Wiosny. Polska i Czechosłowacja w 1968 roku. Red. Łukasz Kamiński, 97-106. Warszawa: Wyd. Instytutu Pamięci Narodowej, 2004.

Piotrowski, Paweł. „W nocy z wtorku na środę.” Biuletyn Instytutu Pamięci Narodowej, nr 8/9 (2003): 52-60.

Rybak, Jarosław. Commando: nieznana historia 62. Kompanii Specjalnej Wojska Polskiego. Warszawa: Wyd. Creatio PR, 2017.

Rybak, Jarosław. „Czeska wojna.” Polityka, sierpień 28, 2010, 57-59.

Rybak, Roman. „Morale jako podstawowy czynnik przygotowania operacji wojskowych. Na przykładzie inwazji wojsk Układu Warszawskiego na Czechosłowację 1968 - operacja «Dunaj»." W Wojny i konflikty zbrojne po 1945 roku. Zbiór studiów. T. 2. Red. Mirosław Giętkowski i Łukasz Nadolski. 203-227. Bydgoszcz: Muzeum Wojsk Lądowych, 2016.

Sadowski, Sławomir. „Powstanie, zasady działania i szkolenia jednostek specjalnych w Ludowym Wojsku Polskim." Bezpieczeństwo. Teoria i praktyka 10, nr 3 (2016): 155-172.

Szczepańska, Anna. „Sytuacja Polaków w Czechosłowacji w latach 1956-1968.” W Między ideologia a socjotechnika. Kwestia mniejszości narodowych $w$ działalności władz komunistycznych - doświadczenie polskie i środkowoeuropejskie. Red. Maria Semczyszyn i Jarosław Syrnyk, 66-85. Warszawa-Szczecin-Wrocław: Wyd. Instytutu Pamięci Narodowej, 2014.

Szewczyk, Radosław. „1 Batalion Szturmowy podczas przygotowań i interwencji w Czechosłowacji w 1968 r." Przegląd Historyczno-Wojskowy 20, nr 3 (269) (2019): 158-177.

Szewczyk, Radosław, „ «Pochmurne lato» i Operacja «Dunaj»." Odkrywca, nr 1 (2018): 48-54.

„Wydarzenia w Czechosłowacji.” Żołnierz Polski, wrzesień 1, 1968.

Wyszczelski, Lech, Działania nieregularne w myśli wojskowej i sztuce wojennej XIX i XX wieku (synteza). Warszawa: Akademia Obrony Narodowej, 2001.

\section{STRESZCZENIE}

\section{Przemysław Benken, Problematyka wykorzystania 1 Batalionu Szturmowego w operacji „Dunaj”}

Tematem niniejszego artykułu jest zaprezentowanie działań 1 Batalionu Szturmowego w toku operacji „Dunaj”. Tekst obejmuje ponadto krótkie omówienie 
genezy sił specjalny w Wojsku Polskim, przygotowania tytułowej jednostki do przemieszczenia się na teren Czechosłowacji, a także krytyczną analizę jej dokonań. Stosunkowo najbardziej szczegółowo opisano akcje specjalne wymierzone przeciwko tzw. nielegalnym ośrodkom dywersji ideologicznej. Uzupełnieniem artykułu jest kilka aneksów przedstawiających wybrane aspekty funkcjonowania batalionu szturmowego w trakcie operacji „Dunaj”, jak również sposób prezentowania jego działań przez propagandę.

Słowa kluczowe: operacja „Dunaj”, 1 Batalion Szturmowy, działania specjalne

\section{SUMMARY}

\section{Przemysław Benken, Questions concerning the Use of the $1^{\text {st }}$ Assault Battalion in Operation „Danube”}

This article mainly concerns the activities of the 1st Assault Battalion during Operation „Danube”. The paper also includes a brief overview of both the origins of Poland's special forces and the preparations associated with the 1st Assault Battalion's deployment to Czechoslovakia. A critical analysis of the unit's achievements is also presented, including the special actions it performed against the so-called illegal centers of ideological subversion. The article is supplemented with several appendices which present selected aspects of the activities of the assault battalion during the operation, as well as the way its activities were propagandized.

Keywords: Operation „Danube”, 1st Assault Battalion, special operations

\section{АННОТАЦИЯ \\ Пшемыслав Бенкен, Проблема использования 1-го штурмового батальона в операции „Дунай”}

Тема данной статьи - действия 1-го штурмового батальона во время операции „Дунай”. Она также включает в себя краткий обзор генезиса спецподразделений Войска Польского, подготовку титульного подразделения к перемещению на территорию Чехословакии и критический анализ ее достижений. Относительно подробно описаны специальные акции против так называемых нелегальных центров идеологической диверсии. Статья дополнена несколькими приложениями, в которых представлены отдельные аспекты деятельности штурмового батальона в ходе операции „Дунай”, а также способы пропагандистского представления его деятельности.

Ключевые слова: операция „Дунай”, 1-й штурмовой батальон, специальные действия 